\title{
Review
}

\section{Growth Factors, Reactive Oxygen Species, and Metformin-Promoters of the Wound Healing Process in Burns?}

\author{
Daniela Miricescu ${ }^{1}$, Silviu Constantin Badoiu ${ }^{2,3, *}$, Iulia-Ioana Stanescu-Spinu ${ }^{1, *}$, Alexandra Ripszky Totan ${ }^{1}$, \\ Constantin Stefani ${ }^{4}$ and Maria Greabu ${ }^{1}$ \\ 1 Department of Biochemistry, Faculty of Dental Medicine, Carol Davila University of Medicine and Pharmacy, \\ 8 Eroii Sanitari Blvd, 050474 Bucharest, Romania; daniela.miricescu@umfcd.ro (D.M.); \\ alexandra.totan@umfcd.ro (A.R.T.); maria.greabu@umfcd.ro (M.G.) \\ 2 Department of Anatomy and Embriology, Faculty of Medicine, Carol Davila University of Medicine and \\ Pharmacy, 8 Eroii Sanitari Blvd, 050474 Bucharest, Romania \\ 3 Department of Plastic and Reconstructive Surgery, Life Memorial Hospital, 365 Grivitei Street, \\ 010719 Bucharest, Romania \\ 4 Department of Family Medicine and Clinical Base, Dr. Carol Davila Central Military Emergency University \\ Hospital, 010825 Bucharest, Romania; constantin.stefani@umfcd.ro \\ * Correspondence: silviu.badoiu@umfcd.ro (S.C.B.); iulia.stanescu@umfcd.ro (I.-I.S.-S.)
}

Citation: Miricescu, D.; Badoiu, S.C.; Stanescu-Spinu, I.-I.; Totan, A.R.; Stefani, C.; Greabu, M. Growth Factors, Reactive Oxygen Species, and Metformin-Promoters of the Wound Healing Process in Burns? Int. J. Mol. Sci. 2021, 22, 9512. https:// doi.org/10.3390/ijms22179512

\section{Academic Editor:}

Aleksandra Klimczak

Received: 31 July 2021

Accepted: 30 August 2021

Published: 1 September 2021

Publisher's Note: MDPI stays neutral with regard to jurisdictional claims in published maps and institutional affiliations.

Copyright: (c) 2021 by the authors. Licensee MDPI, Basel, Switzerland. This article is an open access article distributed under the terms and conditions of the Creative Commons Attribution (CC BY) license (https:/ / creativecommons.org/licenses/by/ $4.0 /)$.

\begin{abstract}
Burns can be caused by various factors and have an increased risk of infection that can seriously delay the wound healing process. Chronic wounds caused by burns represent a major health problem. Wound healing is a complex process, orchestrated by cytokines, growth factors, prostaglandins, free radicals, clotting factors, and nitric oxide. Growth factors released during this process are involved in cell growth, proliferation, migration, and differentiation. Reactive oxygen species are released in acute and chronic burn injuries and play key roles in healing and regeneration. The main aim of this review is to present the roles of growth factors, reactive oxygen species, and metformin in the healing process of burn injuries.
\end{abstract}

Keywords: burns; growth factors; reactive oxygen species; metformin; wound healing; signaling pathways

\section{Introduction}

Currently, burns are the fourth most common type of injury, caused by several factors, mainly hot water, followed by hot tea or milk, hot objects, hot meals, hot oil, chemicals, electricity, sun, embers, and flame [1,2]. Depending on the degree of the damage, burns can be treated at home, by pharmacists, or may require specialist care [1]. Even though in the present there are modern healthcare services, burn-related death rates are increasing every day. Unfortunately, burn wound patients have an increased risk of cutaneous and systemic bacterial infections that can seriously delay the wound healing process [3]. Dead tissue and protein-rich exudate exist in the burn wound, providing a suitable environment for the proliferation and colonization of microbes [3]. When the skin is injured, different cell types such as keratinocytes, fibroblasts, functional cells, and growth factors (GFs) are recruited and involved in wound regeneration [4]. Both in humans and animals, a wound can be defined as damage or disruption of the normal anatomical structure and function, which can be a simple break in the epithelial integrity of the skin, or it can be deeper, affecting the subcutaneous tissue and damaging several structures, such as tendons, muscles, vessels, nerves, parenchymal organs, and bones. Burn-related wounds can be acute or chronic, according to their duration of healing [5]. Compared with acute wounds, the chronic ones have a negative impact worldwide, with huge medical costs for patients and an increased risk of mortality [6]. Chronic wounds are venous, arterial, and diabetic ulcers that are usually associated with burns, advanced age, and several systemic and blood circulation diseases [7]. Worldwide, diabetic foot ulcers represent a major health-care problem [8]. 
For example, in the United States of America, approximately 6.5 million people have chronic ulcers [9]. Chronic wounds can be defined as a pathologic inflammatory state, characterized by a proteolytic microenvironment at the wound site, which can lead to GFs degradation that further delays or impairs the normal wound healing process. Moreover, these types of wounds have a high bacterial load, which will delay the healing process. Clinical trials have reported that topical application of GFs on chronic wounds is for the most part unsuccessful because of their rapid degradation and extremely short half-life [10].

\section{Wound Healing Process-General Aspects}

The healing process is very complex and assumes and includes the following steps: (i) Hemostasis, (ii) inflammation, (iii) cell proliferation/granulation, and iv) the remodeling phase [11-14]. The time-frames specific for each step mentioned above in the process are 1-3 days, 3-20 days, 7-40 days, and 40 days to 2 years, respectively [13]. The normal skin wound healing is a complex process orchestrated by cytokines, GFs, clotting factors, prostaglandins, free radicals, and nitric oxide [15]. In the primary hemostasis and coagulation phase, blood platelets are present, which are small non-nucleated elements derived from megakaryocyte fragmentation exerting various essential functions [13]. Platelets present hemostatic roles such as adhesion, activation, and aggregation recruitment of other platelets and leukocytes. These functions are mediated by various specific receptors that will bind to the ligands localized sub-endothelially after vessel attrition, on other platelets, and even on leukocytes [13]. During wound healing, a coordination between epithelial cells, platelets, endothelial cells, fibroblasts, and macrophages has positive effects (Figure 1) [16].

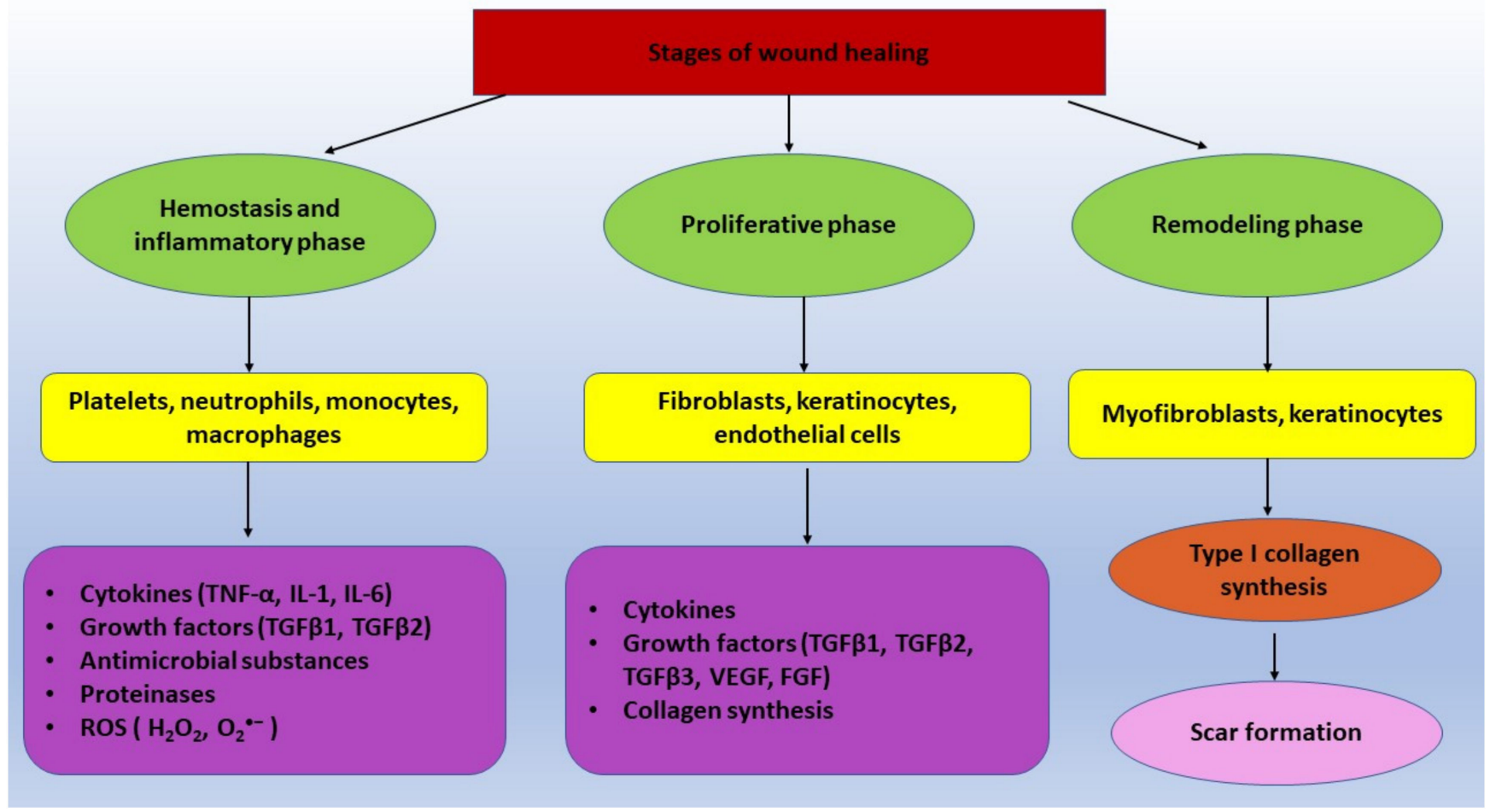

Figure 1. Stages of wound healing.

The inflammatory phase is involved in the cleaning of the pathogens and foreign material from the wound [17]. In a condition like this, vascular permeability is increased, allowing neutrophils and monocytes to move to the wound site [17]. In the regulation of the inflammatory phase, neutrophils, which are the master regulators of this phase, will transform monocytes into macrophages [17]. Further, the macrophages will phagocytize and digest the tissue debris and the remaining neutrophils but will also secrete GFs and cytokines that will promote tissue proliferation and cell migration [17]. Corroborating 
these findings, the inflammatory phase is an elaborate process that involves coordination amongst a diversity of cell types. The first line of defense against tissue injury and bacterial infection is represented by neutrophils, which are granular polymorphonuclear leukocytes (PMN) [18]. Chemotaxis represents the process of migration of neutrophils and other leukocytes to infected or damaged places, accompanied by increased production of chemokines and cytokines [18]. This way, neutrophils stimulate the secretion of pro-inflammatory mediators (TNF- $\alpha$, IL-1 and IL-6), anti-inflammatory cytokines (IL-8), and GFs (vascular endothelial growth factor-VEGF) that further release antimicrobial substances (cationic peptides, eicosanoids) and proteinases (elastase, cathepsin G, proteinase 3, and urokinasetype plasminogen activator) [18]. Macrophages are the key players in the transition from inflammation to proliferation. The absence of macrophages from the inflammatory or the proliferation phase of wound healing will trigger a reduced tissue formation or hemorrhage. In the early stages of wound healing, M1 macrophages are associated with phagocytic activity, stimulating the production of pro-inflammatory mediators [19]. After fulfilling the mentioned roles, $\mathrm{M} 1$ is converted into the M2 subset that is implicated in the synthesis of anti-inflammatory mediators and the production of extracellular matrix (ECM), in the initiation of fibroblast proliferation and angiogenic processes [19]. Moreover, M1 cells have immense phagocytic properties, swallowing the neutrophils that have suffered apoptosis and removing any pathogens or debris in the wound [20]. It has been observed that during the early stages of inflammation, around $85 \%$ of macrophages have the M1 phenotype, while $15 \%$ have the M2 phenotype. At 5-7 days post injury, this ratio is reversed when the wound is mature, where only $15-20 \%$ of macrophages have an M1 phenotype, while the majority of cells that populated the wound have the M2 phenotype. In these conditions, on 5 days post injury, M2 macrophages secrete CD301b, increased levels of anti-inflammatory cytokine (IL-10), and GFs (platelet-derived growth factor-PDGF $\beta$ and transforming growth factor- $\beta 1-T G F-\beta 1)$ [20].

The inflammation phase can be defined as the primary driver of scarring at the wound site, including following burns [21]. Even though inflammation is an important step for proliferative phase stimulation, excessive inflammation may cause impairment in wound healing [22]. The proliferative phase is characterized by the accumulation of cells such as fibroblasts, keratinocytes, and endothelial cells. Proteoglycans, hyaluronic acid, collagen, and elastin-that are ECM matrix components-are implicated in the formation of the granulation tissue [11]. During this phase that may last between days and even weeks, a wide variety of cytokines and GFs, including the TGF- $\beta$ family (TGF- $\beta 1$, TGF- $\beta 2$, and TGF- $\beta 3$ ), the IL family, and angiogenesis factors (vascular epidermal growth factor-VEGF), are released [11]. The granulation tissue presents fibroblasts and ECM collagens. Regarding the matrix, neovascularization is sustained by angiogenesis and vasculogenesis, molecular events that will end after full epidermal coverage of the wounded surface [6]. Fibroblasts are the main agents responsible for the deposition of the new matrix. Collagen is the main component of the mature connective tissue scar, secreted by fibroblasts. Furthermore, fibroblasts secrete type III collagen in the granulation tissue, which represents the predominant form [23]. Angiogenesis is a key step in the formation of granulation tissue. Macrophages, retinal keratinocytes, and vascular smooth muscle cells are able to release VEGF, which possesses a strong ability of promoting angiogenesis [24]. Angiogenesis represents the formation of new blood vessels, an important phase of the healing process that is stimulated by basic fibroblast growth factor (bFGF), TGF- $\beta$, TNF- $\alpha$, and VEGF [25]. Furthermore, neovascularization is required to support the increased proliferation of fibroblasts and keratinocytes [26]. The new blood vessels' formation mediates the transport of nutrients, oxygen, GFs, and circulating cells, which are essential for wound healing and tissue regeneration [27]. In the final stage, the remodeling phase, type III collagen is replaced with type I collagen, and fibroblasts are differentiated into myofibroblasts, further involved in wound contraction and scar maturation [28,29].

Several cell types including the resident fibroblast, adipocytes, fibrocytes, monocytes, mesenchymal cells, and epithelial/endothelial cells can be differentiated into myofibrob- 
lasts [30]. During the normal wound healing process, myofibroblasts significantly disappear at the end of the process via apoptosis [30]. Their presence in the wound tissue is correlated with scar production. Moreover, myofibroblasts are involved in the production of ECM components and enhance the matrix elements' synthesis, such as laminin, glycosaminoglycans, and hyaluronic acid [30]. Marconi and co-workers observed that, in gingival tissue, during the wound healing process, cytokines and GFs stimulate the differentiation of resident fibroblasts into myofibroblasts [30]. Therefore, TGF- $\beta 1$ secreted mostly by M2 macrophages [20] represents the typical inducer of myofibroblast differentiation [30]. Furthermore, the keratinocyte growth factor (KGF) stimulates the release of keratinocytes that may convert fibroblasts into myofibroblasts [29]. Hesketh and colleagues observed in GW2580 mice that M2 macrophages promote scar formation. Acute wounds have an increased M2 macrophages population correlated with high levels of TGF- $\beta 1$ that further induce an increased rate of fibroblast differentiation and rapid wound closure. Unfortunately, in chronic wounds, including diabetic foot ulcers and venous leg ulcers, the typical shift of M1 to M2 macrophages is dysregulated [20].

Reepithelization or the formation of the new tissue assumes the presence of the keratinocytes that migrate to the wound center from the wound edge after suffering molecular, morphological, cytoskeletal, and adhesive changes, called the epithelial-mesenchymal transition [31]. Any aberration in the remodeling phase may lead to excessive wound healing or chronic wounds [11]. In patients who suffered irradiation, delayed wound healing may be a serious clinical problem [32]. In contrast, chronic non-healing wounds are characterized by decreased production of GFs and chemokines, decreased angiogenesis, reduced proliferation and migration of several cell types such as fibroblasts, and an impaired inflammatory response [33]. In addition, diabetic chronic wounds are associated with impaired angiogenesis, leukocyte function, fibroblast proliferation, and keratinocyte migration and proliferation [34].

Extracellular vesicles (EVs) may be an excellent alternative to enhance the wound healing process, especially for diabetic chronic wounds. These vesicles may derive from mesenchymal stem cells (MSC) and contain proteins, lipids, and nucleic acids. Therefore, during skin regeneration, EVs can activate angiogenesis, proliferation, migration and differentiation of endothelial cells, fibroblasts, and keratinocytes [35].

\section{The Impact of Growth Factors on the Healing Process and Their Clinical Applications}

GFs are natural polypeptides involved in cell growth, proliferation, migration, and differentiation that are able to bind to their specific receptors located on the cell surface, further initiating signaling pathways and activating specific signaling molecules, eventually triggering protein synthesis [36,37]. In burn-related chronic wounds, GFs play a crucial role in wound healing because they may restore the physiological wound healing process [38]. In humans and animals, in the healing process, GFs such as PDGFs, FGFs, the epidermal growth factor (EGF), TGF- $\beta$, VEGF, and the granulocyte-macrophage colony stimulating factor (GM-CSF) play key roles [39-42]. In addition, GF deficiencies, including reduced levels of bFGF, PDGF, EGF, and TGF- $\beta$, have been observed in chronic pressure ulcers versus acute wounds [36]. Moreover, the expression of PDGF is more decreased in chronic dermal ulcers than in surgically created acute wounds. These aspects suggest that GF deficiencies are responsible for chronic wounds [36]. Decreased GF activity in the chronic wound may contribute to reduced amounts of ECM synthesis and collagen production [43]. ECM proteins are able to promote angiogenesis and wound healing through GFs binding. The release by the endothelial cells of the protein von Willebrand factor into plasma and in the subendothelial matrix has been shown to regulate angiogenesis [44]. Beside tissue repair, GFs are also omnipresent ingredients of colostrum, milk, and saliva, involved in digestion and nutrition [43]. GFs such as PDGF, FGF-2, IGF, and KGF, have been used in clinical trials, while PDGF is currently approved for application in human medicine [45]. 


\subsection{Fibroblast Growth Factor Family and Wound Healing}

FGFs belong to the growth factor family that includes 23 members, which are involved in angiogenesis, wound healing, embryonic development, and regulation of the endocrine secretion. These diverse biological roles depend on their binding to the cofactor heparin sulphate or Klotho that will form dimers with their receptors. Out of all the FGFs family, FGF-2, FGF-7 (or KGF-1), and FGF-10 (or KGF-2) have been observed to be involved in cutaneous wound healing [46]. FGFs are expressed in heart, liver, skin, and kidney tissues. Out of all FGFs members, FGF-2, $-7,-10$, and -21 are highly expressed in skin tissue, and all except FGF7 regulate fibroblast cell migration and activate the signaling pathway c-Jun Nterminal kinase JNK [47]. In addition, FGFs influence the expression of other GFs involved in the regenerative response, promoting organ regeneration in humans [48]. In addition, FGFs promote homeostatic balance during postnatal life [49]. FGF-1 and -2 are involved in fibroblast growth and trigger angiogenesis, cell migration, and wound healing [50].

bFGF is a member of the FGF, a highly specific mitogenic factor for many cell types, involved in wound repair, angiogenesis, nerve nutrition, and embryonic development [51]. Yang and colleagues have shown that oil bodies that express the oleosin-bFGF fusion protein have an excellent proliferative effect on $\mathrm{NIH} / 3 \mathrm{~T} 3$ cells and animal experiments, decreasing the wound size, and may accelerate the maturation of tissue granulation [51]. Moreover, FGF-2, -9, and -18 are involved in bone regeneration [52]. A positive effect of bFGF has been observed on the periodontal healing of replanted teeth [53]. bFGF is widely used for difficult wound healing treatment [54]. Recombinant human bFGF (rh-bFGF) is a multifunctional growth factor involved in cell growth and reproduction, it promotes capillary regeneration, stimulates epithelial and endothelial proliferation, and improves wound granulation tissue production. As mitogen and chemokine, rh-bFGF increases the activity and promotes the aggregation of fibroblasts [55]. In irradiated wounds, a decreased local level of bFGF in skin was observed to be associated with delayed healing. Radiation decreases bFGF production because it reduces the bFGF message in irradiated tissue. Instead, the supplemental intravenous administration of bFGF may reduce irradiated soft tissue injury [56]. Peng and co-workers observed in rats that the exogenous application of bFGF significantly upgrades the expression of VEGF and TGF- $\beta$ in wound sites and enhances the angiogenesis process and cell proliferation [57]. FGF2 is involved in the proliferation and migration of keratinocytes. Instead, the effect of FGF10 (KGF2) on keratinocytes in the wound healing process appears to emanate from the connective tissue layer [58].

Ramos-Gonzalez $\mathrm{G}$ and colleagues conducted an experimental wound model study that included C57BL/6 mice. Human mesenchymal stromal cells seeded on collagen membranes were implanted in wounds. The control group was represented by animals with wounds without treatment or treated with collagen membranes. The study concluded that wound healing induced by mesenchymal stromal cells is associated with an increase in epithelial progenitor cells and GFs such as bFGF [59].

Xie et al. investigated the effects of bFGF on the hypertrophic scar in a rabbit ear model. The rabbit ear model of wound healing was created and treated with bFGF once daily for 3 months. The results of the study show macroscopic and histologic significant changes between scars treated with bFGF and control scars [60]. bFGF improves the quality of the wound healing process. In adults with second-degree burns, mainly with deep dermal burns, bFGF administration significantly improves the wound healing [61]. Numata et al. reported higher levels of bFGF at the wound edge of gene-knockout mice $(H D C(+/+)$ especially on the third and fifth day of wound healing versus $H D C(-/-)$ mice [62]. Moreover, fibrin may be a target for human bFGF, so the fibrin-binding peptide Kringle1 (K1), derived from human plasminogen, was fused to human bFGF. The recombinant K1bFGF presents increased fibrin and plasma-clot-binding ability that may induce neovascularization and enhance wound healing when applied to plasma clots [63]. Guo et al. used human-like collagen (HLC) cross-linked with transglutaminase (TG) to synthesize HLC/TG hydrogel, 
which was further loaded with bFGF, conducive to skin regeneration in the structure and function [64].

\subsection{Epidermal Growth Factor and Wound Healing}

EGF was the first growth factor isolated, which is involved in keratinocyte migration, fibroblast function, and granulation tissue formation [65]. Human EGF (hEGF) is a member of the GFs family that activates EGF receptors [66]. hEGF is synthesized and secreted by multiple tissues and organs of the human body. Several signaling pathways are activated by hEGF via receptors that will further promote the regulation of cell proliferation, differentiation, and migration [66]. EGF family members are constantly expressed in the tear and its receptors are expressed in ocular surface tissues [67]. EGF is recognized as an excellent wound healing factor due to its therapeutic roles, such as stimulating skin cell growth, proliferation, and differentiation [68]. In an experimental rat model, EGF in combination with Enoxparin has a synergistic effect and significantly contributes to thrombus resolution [69]. Moreover, EGF may be involved in the prevention of anastomotic leakage of esophageal atresia by accelerating the wound healing process and increasing the stability of the anastomotic line [70]. EGF might provide significant wound healing stimulation for chronic wounds compared with acute wounds [71]. The EGF receptor is widely expressed in mammals, without hematopoietic cells. EGF administration promotes migration and proliferation of both epithelial and mesenchymal skin cells [72]. Retinoic acid up-regulates the expression of EGFR in the treatment of deep partial-thickness burns using $\mathrm{HaCaT}$ cells [73]. A combination of EGF with curcumin bandage bioconjugate (EGF-Cur B) loaded with bone-marrow-derived mesenchymal stem cells at the wound site for diabetic wounds leads to the formation of granulation tissue, collagen deposition, and angiogenesis versus the control group [74]. EGF and FGF may regulate different key factors of wound healing in all stages. In addition, EGF and TGF- $\beta 1$ synergistically stimulate cell migration, and both increase MMP-9 function and increase extracellular signal-regulated kinase ERK1/2 activation [75].

Kao et al. tested in vivo and in vitro the effects of lidocaine and human EGF-incorporated PLGA nanofibers as an anti-adhesive membrane for surgical wound healing. It is well known that hEGF facilitates dermal regeneration by promoting the stimulation, proliferation, and migration of keratinocytes, endothelial cells, and fibroblasts. The study concluded that the combination used offers post-operative pain relief and wound healing [76].

In the treatment of chronic wounds, EGF conjugated with hyaluronate (HA) enhances the healing effect [77]. This aspect is sustained by the long-term stability against enzymatic degradation. The therapeutic effect is manifested by the higher biological interaction with HA receptors on skin cells [77]. Moreover, exogenous EGF treatment increases the rate of wound healing in a three-dimensional stem cell-derived model of vocal fold mucosa [78]. Kaya and co-workers tested the effect of EGF on rats after an early burn. The animals were divided in three groups: Group 1 (no post-burn treatment), group 2 (treated with physiological saline solution), and group 3 (EGF injected intra-dermally into the stasis zone). The highest surviving rate was observed in group $3(70.2 \%)$ compared with the others two group. No difference was detected between groups 1 and 2 [79]. EGF protects the zone of stasis tissue from burn damage [79]. It can also correct the pseudo-healing of traumatic tympanic membrane perforations, after daily application over six months, to keep the membrane moist [80]. In patients with diabetic foot ulcers, parenteral administration of EGF on epithelial tissue has a positive effect on the healing process [81]. Dogan and colleagues conducted an experimental study performed on male Wistar-Albino rats divided into non-diabetic and diabetic rats and reported that EGF loaded in a gelatine-microsphere improves wound healing both in normal and diabetic rats [82]. Wei et al. tested the effect of a recombinant (rhEGF) using HaCaT and L929 cells [83]. In vitro, a concentration of $10 \mathrm{ng} / \mathrm{mL}$ of rhEGF promotes the proliferation and migration of epithelial cells and fibroblasts. On the other hand, in vivo, vacuum sealing drainage combined with rhEGF, can improve wound healing better than the other treatments [83]. 
Moreover, the fabrication of scaffolds such as poly ( $\varepsilon$-caprolactone) (PCL) containing EGF has high potential for wound-healing applications [84]. Kalay and co-workers reported that EGF may act like an antioxidant in wound tissue. Scavenging the wound against toxic compounds may contribute to the healing in earlier stages, becoming a possible antioxidant used in therapies [85].

\subsection{Transforming Growth Factor-Beta Family and Wound Healing}

The TGF- $\beta$ superfamily includes three isoforms, TGF- $\beta 1,-\beta 2$, and $-\beta 3$, coded by genes with different locations in various chromosomes [86]. TGF- $\beta$ are soluble extracellular proteins, which regulate the development in both vertebrates and invertebrates [87]. TGF- $\alpha$ belongs to the EGF family; it is a 50-amino-acid polypeptide, which in humans has 10 members, isolated from a conditioned medium of virally transformed cells and tumor cells [88]. TGF- $\beta$ members regulate cell functions such as migration, apoptosis, proliferation, and differentiation [87]. TGF- $\beta$ is secreted in a latent form by most cells and is activated via TGF- $\beta$ receptor signaling [89]. TGF- $\beta$ also plays a major role in myofibroblast transdifferentiation and has been involved in numerous fibrotic eye diseases [90]. TGF- $\beta 1$ is found in the granulation tissue of diabetic foot ulcers [11]. This cytokine accelerates wound healing [91] because it is a key regulator of the mesenchymal cells, involved in the production and remodeling of the ECM [92]. TGF- $\beta$ inhibits tissue protease production and stimulates the secretion of the inhibitors of matrix metalloproteinases (MMPs) [93]. Using animal models, the expression of endogenous TGB- $\beta 1$ is reduced in impaired wound healing, while its exogenous addition may improve healing [92,94]. Peplow and co-workers observed in cutaneous wounds of animals with diabetes that TGF- $\beta$ has decreased gene expression and content in early phases of healing for diabetic wounds versus the nondiabetic wounds [95]. In horses, elevated levels of TGF- $\beta$ may result in the production of exuberant granulation tissue [96]. Rorison and co-workers reported that in patients with excellent post-burn healing, in the first two weeks post-injury, plasma levels of TGF- $\beta 1$ rapidly increase to significantly higher levels and then rapidly decrease. However, in patients who develop hypertrophic scarring, plasma levels of TGF- $\beta$ levels in the early stages after a burn are absent [97].

\subsection{Vascular Endothelial Growth Factor Family and Wound Healing}

The VEGF family is a group of homodimeric proteins that contain six members: VEGF-A, VEGF-B, VEGF-C, VEGF-D, VEGF-E, and the Placental growth factor (PlGF) [98]. VEGF is the most abundant form, a specific mitogen for endothelial cells, involved in the proliferation, migration, and activation of endothelial cells [98,99]. Moreover, VEGF promotes permeability and fenestration of blood vessels. VEGF-C and -D are important for lymphangiogenesis, while VEGF-B has a role in embryonic angiogenesis. PlGF is involved in pathological angiogenesis [98]. Beside endothelial cells, many cell types involved in the wound healing mechanism possess VEGF receptors, such as keratinocytes, mesenchymal stem cells [100], fibroblasts, smooth muscle cells, platelets, neutrophils, and macrophages [101]. Humans have two types of VEGF receptors, Flt-1 (VEGFR-1) and KDR (VEGFR-2), both with high affinity and members of the type III tyrosine kinase family [101]. In the skin, VEGF is produced by keratinocytes, macrophages, platelets, and tumor cells [100]. During granulation tissue formation, capillaries and lymphatic vessels are formed from the pre-existing vessels at the wound site with the help of FGF and VEGF [102-104]. VEGF can induce healing by aiding in vascular permeability and prevents the inflammatory cells from migrating to the injured place and accelerates the proliferation and migration of endothelial cells [102]. Lord et al. conducted an experimental study on animals and observed that plasmid DNA encoding perlecan domain I and VEGF189loaded scaffolds promote dermal wound healing in normal and diabetic rats. The treatment administered to rats increased the number of blood vessels and sub-epithelial connective tissue matrix components [105]. Shi and co-workers performed an experimental study using rat epidermal stem cells ESCs that have been treated with exogenous VEGF in order 
to explore the healing of deep partial-thickness burn wounds. The study concluded that VEGF can promote the healing of deep partial-thickness burn wounds in rats [106]. The clinical study conducted by Li et al. that included children with femoral fracture after surgery explores the effects of VEGF incorporated into silver nanoparticles (Ag NPs) on the wound healing process. The results reported that Ag NPs loaded with VEGF improve the femoral fracture healing and especially the blood vessel repair [107].

Vijayan et al. prepared a heparin-based Chitosan-Polyethylene glycol (CS-PEG-H) scaffold, which was able to deliver GFs, such as VEGF and bFGF, in a controlled manner to the wound site. The study revealed an elevated wound healing rate, including neovascularization versus the control on day 10 [108]. Saaristo and co-workers conducted an experimental study on genetically diabetic $\mathrm{db} / \mathrm{db}$ mice to explore the effects of VEGF-C and the role of endogenous VEGF-C and VEGF-D during tissue repair. The results of the study concluded that VEGF-C enhances the wound healing process and attests to its applicability in the treatment of complicated diabetic wounds [109]. LDL, but not oxLDL, enhances the expression of VEGF. Bogachkov and co-workers observed in an experimental study that hypercholesterolemic apolipoprotein E-deficient $\left(\mathrm{ApoE}^{-/-}\right)$mice display a delayed wound healing process compared to age-matched C57/BL6 wild-type controls after skin punch biopsy [110].

\subsection{Insulin-Like Growth Factor Family and Wound Healing}

The IGF family is composed of two peptide ligands, IGF-1 and IGF-2, and the hormone insulin [111]. IGF-1 is produced mainly by the liver under the control of the growth hormone, being involved in body growth. Apart from its role in growth, IGF-1 plays key roles in maintaining the normal function of kidneys, cardiovascular system, and brain [112]. Moreover, IGF plays an important role in cartilage homeostasis, maintaining a balance between proteoglycan synthesis and breakdown [113]. Regarding IGF-1 and wound healing, the growth factor has multiple functions, having a chemotactic effect on endothelial cells, stimulating the proliferation of fibroblasts and keratinocytes, and enhancing the wound strength. Botusan and co-workers conducted a study to observe the role of circulating IGF-I on the wound healing rate. The study included mice with deficiency of liver-derived IGF-I (LI-IGF-I-/- mice) divided in two groups, the normoglycemic-the control-group and the second one composed of diabetic animals and concluded that IGF-I does not affect wound healing in the two mice groups [112]. In contrast, Gong and co-workers explored the effects of exogenous IGF-1 on the healing process of skin ulcers in diabetic male rats. The experimental study animals were divided into the control group, the model group, and the IGF-1 treatment group, which received different doses of IGF-1. The study results reported that IGF-1 promotes the wound healing of skin ulcers in diabetic rats [114]. Shinchi et al. revealed in a rabbit model that IGF-1 may sustain the collagen release and significantly improves the wound healing and may prevent the urethral stricture after urethral injury [115]. IGF-1 has a therapeutic effect even in the healing of gingival mucosa damage [116]. Using rats, Todorović et al. evaluated the expression of IGF-1 in skin cells and its systemic and cutaneous tissue concentrations during the acute phase of wound healing. The study results support a paracrine role of IGF-I during the acute phase of a wound [117].

Reckenbeil and colleagues investigated the effects of IGF1 on proliferation, wound healing, and differentiation processes on the human periodontal ligament. The study concluded that an improvement in wound healing and proliferation processes was observed, as well as sustained cell differentiation under inflammatory stimuli [118]. Additionally, Balaji and co-workers demonstrated, using two different models (in vivo and in vitro), that IGF-1 enhances the wound healing process and induces angiogenesis via a VEGF-independent pathway in chronic wounds [119]. Using Wistar adult male rats, divided into diabetic and non-diabetic, it has been revealed that topical administrations of $1 \%$ and 3\% IGF-1 creams enhance the expression of myofibroblasts in the rats' wound-healing process [120]. 


\subsection{Keratinocyte Growth Factor and Wound Healing}

In an injury, keratinocytes are involved in the reepithelization process, interacting with dermal cells and collagen-rich ECM to re-establish the coverage of the wound bed [121]. KGF stimulates the multiplication and migration of keratinocytes [122] and induces cell proliferation and motility [123]. Devalliere et al. investigated in vivo the healing effect of KGF and the cellular protective peptide (ARA290) fused with the elastin-like peptide (ELP). The study was performed on a diabetic wound model and tested the effect of ARA290-ELP and KGF-ELP alone or in combination, and it revealed that ARA290-ELP was able to accelerate healing by increasing angiogenesis. Both ARA290-ELP and KGF-ELP are promising new therapeutics for the treatment of chronic wounds [124]. Bienert et al. evaluated the capacity of FGF-, EGF-, KGF-, PDGF-, or VEGF to promote wound healing in vitro. The study confirms their potential as wound-healing therapies [125]. Chomiski and colleagues tested the impact of KGF treatment on the expression of wound-healing-related genes using keratinocyte cells culture obtained from burn patients. The study included keratinocyte cells divided into four groups, as follows: TKB (KGF-treated keratinocytes from burn patients), UKB (untreated keratinocytes from burn patients), TKC (KGF-treated keratinocytes from controls), and UKC (untreated keratinocytes from controls) and concluded that there is no difference between wound-healing-related genes expression [126]. Moreover, in corneal injury, KGF-2 manifests better effects in re-epithelialization, acceleration of migration, and reduction of scar formation, compared with bFGF [127]. Hydroxyethyl-methacrylate (HEMA) copolymers labelled with KGF increase the release to the wound interface during the first $20 \mathrm{~min}$ of the treatment and enhance the potential of re-epithelialization [128].

\subsection{Granulocyte-Macrophage Colony Stimulating Factor and Wound Healing}

GM-CSF, which is the founding member of the $\beta$ common cytokine family, was identified for the first time in the context of hematopoiesis. GM-CS together with the other two family members, IL-3 and IL-5, are pleiotropic regulators of inflammation in the response to pathogens. Moreover, these cytokines are involved in autoimmune diseases and cancer progression [129]. GM-CSF plays an essential role in the wound healing cascade, being involved in the stimulation and recruitment of keratinocytes, macrophages, and fibroblasts [130] and it regulates the inflammatory response [131]. Controlled trials have shown that GM-CSF is able to accelerate the healing of chronic wounds [130]. GM-CSF is a pleiotropic cytokine that can activate granulocyte and macrophage cell lineages, even involved in wound healing of human corneal epithelial cells [132]. The recombinant human granulocyte macrophage colony stimulating factor (rhGM-CSF) presents a good effect on healing in both deep burn wounds and leprosy ulcers. The healing potential of rhGM-CSF in second-degree burns is very important, because these burns represent a dilemma regarding the medical intervention; sometimes the surgery may be carried out rapidly, other times it should be delayed until remnant dermal components are reepithelialized [133]. Li and colleagues published the results of a systematic review and meta-analysis and supported the potential of rhGM-CSF to be safe for the treatment of the deep second-degree burns [134]. Chi et al. tested the effect of rhGM-CSF for healing burns on children. The subjects were randomly divided into two groups, an experimental group that received external rhGM-CSF gel and a control group who received rhGM-CSF gel matrix components. After the application on the burn surface of rhGM-CSF, the healing time was shorter, without significant adverse reactions [135]. Sun and co-workers assessed the effects of rhGM-CSF gel in patients with full-thickness frostbite wounds on the foot and hand. Topical administration of the rhGM-CSF gel has beneficial effects, shortening the time of wound healing and reducing the inflammatory response of the wound [136]. Moreover, Lim et al. explored the effect of GM-CSF on vocal fold wound healing, both in vivo and in vitro, and confirmed its therapeutic potential promoting regeneration [137]. Exogenous administration of GM-CSF in diabetic mice enhanced wound healing, associated with elevated levels of IL- 6 and monocyte chemoattractant protein- 1 that are correlated with 
increased neovascularization, and infiltration of macrophages and neutrophils. By contrast, GM-CSF did not present any beneficial effects in nondiabetic wound healing [138].

\subsection{Platelet-Derived Growth Factor Family and Wound Healing}

The PDGF family contains homo and heterodimeric GFs such as PDGF-AA, PDGF$A B$, PDGF-BB, PDGF-CC, and PDGF-DD, exerting their functions after binding to transmembrane tyrosine kinase receptors. PDGF has chemotactic properties on neutrophils, monocytes, and fibroblasts. Moreover, it enhances fibroblasts proliferation, their contract to collagen matrices, ECM production, and finally induces the myofibroblast phenotype in these cells [139]. In wound fluid, PDGF is released from degranulating platelets. Studies performed in vivo have shown that PDGF increases capillaries' structural integrity by the recruitment of pericytes and smooth cells. During the epithelization phase of wound healing, PDGF is involved in the up-regulation of IGF-1 and thrombospondin-1 [140]. During tissue repair, various cell types are able to express PDGF-AA, having a mitogen effect on mesenchymal cells that express the receptor PDGF-R $\alpha$. After binding to the receptor PDGF-R $\alpha$, PDGF will play an important role in the granulation tissue formation and myofibroblast differentiation/maturation. The expression of PDGF-AA is reduced in mice with impaired wound healing [141].

\section{Oxygen Metabolism and Wound Healing Process}

For normal wound healing, a proper oxygen supply is needed, which is involved in cell proliferation, migration, and angiogenesis, enhancement of collagen deposition, and epithelization of regenerative tissue [142]. Mitochondria, endoplasmic reticulum (ER), peroxisomes, several oxidase enzymes, and phospholipid metabolism can generate reactive oxygen species (ROS), both free radicals and nonradical species. Hydrogen peroxide $\left(\mathrm{H}_{2} \mathrm{O}_{2}\right)$ is the main ROS produced in wounds by NADPH oxidase (NOX), which acts as a chemotactic signal in the first minutes after wounding [143]. Beside $\mathrm{H}_{2} \mathrm{O}_{2}, \mathrm{NOX}$ can generate anion superoxide $\left(\mathrm{O}_{2}^{\bullet-}\right)$, both having anti-microbial properties, and may be able to destroy the surrounding tissue and cells $[144,145]$. Neutrophils have a chemotactic response to exogenous $\mathrm{H}_{2} \mathrm{O}_{2}$ [146]. During the inflammatory phase of the chronic wounds, excessive neutrophils and macrophages generate elevated levels of ROS [147]. Likewise, during the $\gamma$ ) and pro-inflammatory cytokines (IL-1, IL-12, TNF- $\alpha$ ) produce $\mathrm{O}_{2}^{--}$and $\mathrm{H}_{2} \mathrm{O}_{2}$ [148]. On the other hand, $\mathrm{H}_{2} \mathrm{O}_{2}$ may increase the expression of mRNA for IL-6, IL-8, and TNF- $\alpha$ [149]. Moreover, $\mathrm{O}_{2}^{--}$released by neutrophils in chronic wounds has been shown to be increased by $170 \%$, compared to acute wounds [147]. ROS generated in wounds play a key role in healing and regeneration [150]. During the respiratory burst, the isoform NOX2 plays a predominant role in the anti-microbial fight, being responsible for the production of huge amounts of ROS. Thus, inside phagocytes, elevated concentrations of ROS will have a toxic effect for phagocytosed microbes by DNA damage, lipid peroxidation, and amino acid oxidation [151]. Redox signaling is important for cellular renewal, migration, and proliferation, while an excess of ROS perturbates tissue homeostasis [152]. Oxidative stress (OS) affects cell growth, while in the absence of reactive nitrogen species (RNS), ROS exert a slight positive effect on cell migration and wound healing that is not associated with cellular morphology change [153]. Injectable ROS have the potential of healing, while oxidative damage induced by ROS has a negative effect [154]. Currently, hyperbaric oxygen therapy is used in the medical field in a variety of disorders, including radiation-induced tissue injuries, non-healing states associated with ischemia, and malignant neoplasms [143]. By contrast, decreased levels of $\mathrm{ROS}$ such as $\mathrm{O}_{2}^{-}$and $\mathrm{H}_{2} \mathrm{O}_{2}$ have growth factor-like properties that may induce DNA synthesis in quiescent cells and expression of c-fos and c-myc genes associated with proliferation [155]. $\mathrm{H}_{2} \mathrm{O}_{2}$ is able to activate several signaling pathways, including phosphatases and protein kinases, and even transcription factors [156]. 


\section{Growth Factors, Reactive Oxygen Species and Signaling Pathways Involved in Wound Healing}

GFs may activate the phosphatidylinositol 3-kinase/protein kinase B (PI3K/AKT) pathway by phosphorylation, promoting angiogenesis. This molecular pathway has important cellular functions including cell adhesion, migration, and angiogenesis [157]. VEGF activates PI3K/AKT and the mitogen-activated protein kinases (MAPK) signaling pathways $[158,159]$. MAPK is activated by keratinocytes, predominant cells in the epidermis [160]. In many types of cells and tissues, the MAPK signaling pathway is involved in inflammation, cell proliferation, and differentiation [161]. The MAPK family are serine/threonine kinases, including three subfamilies, extracellular signal-regulated kinases 1 and 2 (ERK1/2), P38, and JNK/SAPK, mediating a variety of cell functions, such as proliferation (ERK1/2) and migration [162]. ERK1/2, JNK, and p38 MAPK have the following activation sites: Thr202/Tyr204, Thr183/Tyr185, and Thr180/Tyr182, respectively [163]. The expression of TNF- $\alpha$, which is necessary for the initiation of wound healing process, depends on the activation of MAPK, p38, JNK, ERK, and on the nuclear factor (NF) $k B$ pathway [164]. It has been shown in vitro that JNK was able to induce keratinocyte migration and wound repair, while its inhibition suppressed cell proliferation at the wound site, and further delayed wound closure [165]. The EGF receptor (EGFR) located on the cell membrane stimulates the MAPK signaling pathway, which in turn initiates various biological processes, such as the proliferation/differentiation of cells, tissue remodeling, and wound repair [166]. ERK plays a central role in the regulation of cell migration, proliferation, differentiation, and cell survival [167]. While the precise role of the p38 MAPK signaling pathway during wound healing has not yet been fully elucidated, recent studies have suggested its involvement in keratinocytes' migration [167]. When the NF- $\mathrm{kB}$ pathway is activated by inflammatory stimuli, it migrates to the cell nucleus, binds with DNA molecules, and induces the transcription of a wide variety of genes involved in inflammation, proliferation, migration, cell cycling, and inhibition of apoptosis [167]. An inappropriate activation of MAPK, especially of JNK, is considered to have a critical role in insulin resistance development [168]. ROS and RNS can modulate all three members of the MAPK family signaling pathway [169] and PI3K/AKT [170]. FGF receptors phosphorylate specific Tyr residues that mediate the interaction with cytosolic adaptor proteins of the signaling pathways MAPK and PI3K/AKT [171].

\section{Metformin and Wound Healing}

Metformin is a biguanide, considered the most used hypoglycemiant drug in type 2 diabetes mellitus [172], being the first-line therapeutic agent in diabetic patients [173]. In severe burns, metformin is used for the long-term control of glycemia [174]. It is important to know that, in severely burned patients, metformin is as effective as insulin in lowering the serum glucose levels and rarely produces hypoglycemia [174]. It acts at multiple levels on the glucose metabolism (reducing hepatic gluconeogenesis, increasing insulin sensitivity, enhancing peripheric glucose uptake, increasing nonoxidative glucose metabolism) [175], lipid metabolism (augmenting the oxidation of fatty acids in liver and decreasing lipogenesis) [175], protein metabolism (increasing the rate of protein synthesis) [176], energetic metabolism [177], and has influence upon inflammation (mainly anti-inflammatory) [178-180] and mitophagy (increasing mitophagy) [181,182]. We must consider the influence of metformin upon wound healing in two ways: Indirectly, by acting upon the metabolisms and inflammation, and directly, by acting upon the scarring and epithelization processes.

a. The indirect effect. Metformin is one of the main drugs used for the pharmacological modulation of the hypermetabolic state and the systemic inflammatory response, which characterizes severe burns [174]. Metformin administration results in controlling hyperglycemia comparable to insulin administration, but with a lower risk for iatrogenic hypoglycemia [174]. Metformin reduces lipogenesis [175] and increases the rate of protein synthesis [176,183]. It has been proved that metformin administration decreases insulin 
resistance in liver, fat, and skeletal muscle with overall reduction of the hypercatabolic state of severely burned patients [184-186]. Better control of the prolonged hypercatabolic state in severe burns accelerates the wound healing, diminishes the rate of infection, and improves the survival [174,187].

By increasing the protein synthesis rate $[174,181]$, decreasing insulin resistance $[175,176]$, and controlling hyperglycemia [174], metformin creates the metabolic premises for better and faster healing of the wounds and facilitates the skin graft take. These effects were proven in clinical trials in burned patients $[172,185]$ and in experimental studies in diabetic rats [188]. Many burns surgeons and intensive burn care doctors have been noticing that a mitigation of the hyperglycemic-hypercatabolic state of the severe burned patient is followed by more rapid wound healing and improved survival rates [187]. In experimental models, it was revealed that metformin improved skin flap survival through the Nitric Oxide (NO) system [189].

Experimental studies on animal models recently demonstrated that metformin modulates the adenosine monophosphate-activated protein kinase (AMPK)-mammalian target of rapamycin (mTOR)-transcription factor EB (TFEB) pathway [190] (Figure 2), which is known to regulate the autophagy process [191].

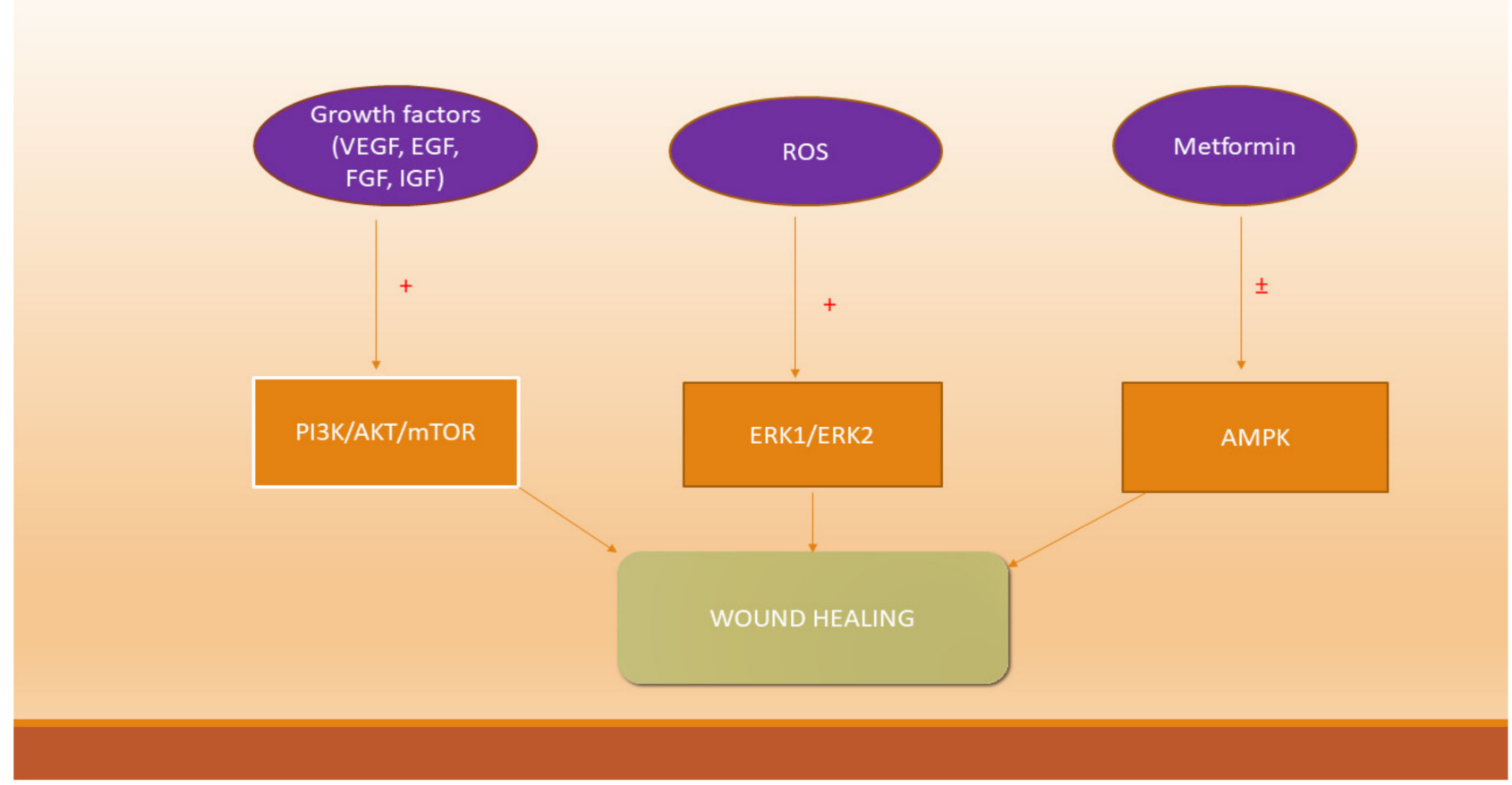

Figure 2. Growth factors, reactive oxygen species, metformin, and signaling pathways involved in the wound healing process (+ activation, - inhibition).

The activation of autophagy results in the inhibition of apoptosis, stimulation of angiogenesis, and reduction of oxidative stress, with consequent better survival of random skin flaps [190].

b. The direct effect. There are studies concerning the direct effect of metformin upon the healing process of wounds. In animal models, it appears that metformin inhibits the wound healing; in human patients with diabetes mellitus and foot ulcers, metformin increases the ulcer size [192]. These effects are explained by the fact that metformin reduces cell (keratinocytes) proliferation, by interfering at least with AMPK and mTOR [193,194], resulting in altering the cell cycle of keratinocytes, without inducing apoptosis [192].

Clinical studies on pediatric burned patients revealed that metformin inhibits the epithelial-mesenchymal transition (EMT) in fibroblasts isolated from burned patients [195]. Practically, metformin downregulates genes related to fibrosis and the epithelial-mesenchymal transition [195]. Furthermore, metformin mitigates the proliferation of fibroblasts and of 
keratinocytes [192,195]. This type of metformin action might not be beneficial for the burned wound healing per se but might be useful for preventing hypertrophic scarring post-burns. Further studies need to be developed in order to quantify the effects of metformin on wound healing in burned patients.

\section{Conclusions}

The wound healing process involves the following steps: Hemostasis, inflammation, cell proliferation, and tissue remodeling, with platelets, neutrophils, monocytes, macrophages, fibroblasts, keratinocytes, and myofibroblasts all participating. GFs are natural polypeptides present in a higher concentration in acute burn injuries, while in chronic ones, their concentration is more decreased. ROS are produced mainly by the NADPH family, and $\mathrm{H}_{2} \mathrm{O}_{2}$ and $\mathrm{O}_{2}^{\bullet-}$ are especially elevated in chronic wounds versus the acute form and are implicated in the anti-microbial fight and further in healing. Several GFs are able to activate the PI3K/AKT/mTOR or MAPK signaling pathway, promoting cell growth, migration, proliferation, and survival.

Author Contributions: Conceptualization, D.M., M.G., I.-I.S.-S., S.C.B., C.S. and A.R.T.; methodology, S.C.B., D.M., M.G. and I.-I.S.-S.; software, C.S. and A.R.T.; validation, M.G. and A.R.T.; formal analysis, C.S.; investigation, S.C.B., D.M., M.G., I.-I.S.-S., C.S. and A.R.T.; resources, S.C.B., D.M., M.G. and C.S.; data curation, S.C.B., C.S. and A.R.T.; writing-original draft preparation, D.M., I.-I.S.-S. and S.C.B.; writing—review and editing, M.G., S.C.B., A.R.T. and C.S.; visualization, I.-I.S.-S. and C.S.; supervision, M.G. and A.R.T.; project administration, M.G., S.C.B., I.-I.S.-S. and C.S. All authors have read and agreed to the published version of the manuscript.

Funding: This research received no external funding.

Institutional Review Board Statement: Not applicable.

Informed Consent Statement: Not applicable.

Conflicts of Interest: The authors declare no conflict of interest.

\section{References}

1. Davies, K.; Johnson, E.L.; Hollén, L.; Jones, H.M.; Lyttle, M.D.; Maguire, S.; Kemp, A.M.P. Incidence of medically attended paediatric burns across the UK. Inj. Prev. 2020, 26, 24-30. [CrossRef] [PubMed]

2. Asena, M.; Aydin Ozturk, P.; Ozturk, U. Sociodemographic and culture results of paediatric burns. Int. Wound J. 2020, 17, 132-136. [CrossRef] [PubMed]

3. Said, A.; Wahid, F.; Bashir, K.; Rasheed, H.M.; Khan, T.; Hussain, Z.; Siraj, S. Sauromatum guttatum extract promotes wound healing and tissue regeneration in a burn mouse model via up-regulation of growth factors. Pharm. Biol. 2019, 57, 736-743. [CrossRef] [PubMed]

4. Goodarzi, P.; Falahzadeh, K.; Nematizadeh, M.; Farazandeh, P.; Payab, M.; Larijani, B.; Beik, A.T.; Arjmand, B. Tissue engineered skin substitutes. Adv. Exp. Med. Biol. 2018, 1107, 143-188.

5. Velnar, T.; Bailey, T.; Smrkolj, V. The wound healing process: An overview of the cellular and molecular mechanisms. J. Int. Med. Res. 2009, 37, 1528-1542. [CrossRef] [PubMed]

6. Jimi, S.; Takagi, S.; De Francesco, F.; Miyazaki, M.; Saparov, A. Acceleration of skin wound-healing reactions by autologous micrograft tissue suspension. Medicina 2020, 56, 321. [CrossRef]

7. Felician, F.F.; Yu, R.H.; Li, M.Z.; Li, C.J.; Chen, H.Q.; Jiang, Y.; Tang, T.; Qi, W.Y.; Xu, H.M. The wound healing potential of collagen peptides derived from the jellyfish Rhopilema esculentum. Chin. J. Traumatol. 2019, 22, 12-20. [CrossRef]

8. Zhu, Y.; Wang, Y.; Jia, Y.; Xu, J.; Chai, Y. Roxadustat promotes angiogenesis through HIF-1alpha/VEGF/VEGFR2 signaling and accelerates cutaneous wound healing in diabetic rats. Wound Repair Regen. 2019, 27, 324-334. [CrossRef]

9. Nesi-Reis, V.; Lera-Nonose, D.S.S.L.; Oyama, J.; Silva-Lalucci, M.P.P.; Demarchi, I.G.; Aristides, S.M.A.; Teixeira, J.J.V.; Silveira, T.G.V.; Lonardoni, M.V.C. Contribution of photodynamic therapy in wound healing: A systematic review. Photodiagnosis Photodyn. Ther. 2018, 21, 294-305. [CrossRef] [PubMed]

10. Vijayan, A.; James, P.P.; Nanditha, C.K.; Kumar, G.S.V. Multiple cargo deliveries of growth factors and antimicrobial peptide using biodegradable nanopolymer as a potential wound healing system. Int. J. Nanomed. 2019, 14, 2253-2263. [CrossRef] [PubMed]

11. Wang, P.H.; Huang, B.S.; Horng, H.C.; Yeh, C.C.; Chen, Y.J. Wound healing. J. Chin. Med. Assoc. 2018, 81, 94-101. [CrossRef] [PubMed]

12. Zhang, X.; Kang, X.; Jin, L.; Bai, J.; Liu, W.; Wang, Z. Stimulation of wound healing using bioinspired hydrogels with basic fibroblast growth factor (bFGF). Int. J. Nanomed. 2018, 4, 3897-3906. [CrossRef] 
13. Garraud, O.; Hozzein, W.N.; Badr, G. Wound healing: Time to look for intelligent, natural immunological approaches? BMC Immunol. 2017, 21, 23. [CrossRef]

14. Elbialy, Z.I.; Atiba, A.; Abdelnaby, A.; Al-Hawary, I.I.; Elsheshtawy, A.; El-Serehy, H.A.; Abdel-Daim, M.M.; Fadl, S.E.; Assar, D.H. Collagen extract obtained from Nile tilapia (Oreochromis niloticus L.) skin accelerates wound healing in rat model via up regulating VEGF, bFGF, and alpha-SMA genes expression. BMC Vet. Res. 2020, 24, 352. [CrossRef] [PubMed]

15. Dam, D.H.M.; Paller, A.S. Gangliosides in diabetic wound healing. Prog. Mol. Biol. Transl. Sci. 2018, 156, 229-239. [PubMed]

16. Eroglu, Z.T.; Kurtis, B.; Altug, H.A.; Sahin, S.; Tuter, G.; Baris, E. Effect of topical ozonetherapy on gingival wound healing in pigs: Histological and immuno-histochemical analysis. J. Appl. Oral Sci. 2018, 27, e20180015. [CrossRef] [PubMed]

17. Han, G.; Ceilley, R. Chronic wound healing: A review of current management and treatments. Adv. Ther. 2017, 34, 599-610. [CrossRef]

18. Reinke, J.M.; Sorg, H. Wound repair and regeneration. Eur. Surg. Res. 2012, 49, 35-43. [CrossRef]

19. Sorg, H.; Tilkorn, D.J.; Hager, S.; Hauser, J.; Mirastschijski, U. Skin wound healing: An update on the current knowledge and concepts. Eur. Surg. Res. 2017, 58, 81-94. [CrossRef]

20. Hesketh., M.; Sahin, K.B.; West, Z.E.; Murray, R.Z. Macrophage phenotypes regulate scar formation and chronic wound healing. Int. J. Mol. Sci. 2017, 18, 1545. [CrossRef]

21. Martin, P.; Nunan, R. Cellular and molecular mechanisms of repair in acute and chronic wound healing. Br. J. Dermatol. 2015, 173, 370-378. [CrossRef] [PubMed]

22. Berksoy Hayta, S.; Durmuş, K.; Altuntaş, E.E.; Yildiz, E.; Hisarciklıo, M.; Akyol, M. The reduction in inflammation and impairment in wound healing by using strontium chloride hexahydrate. Cutan. Ocul. Toxicol. 2018, 37, 24-28. [CrossRef]

23. Gonzalez, A.C.D.O.; Costa, T.F.; Andrade, Z.D.A.; Medrado, A.R.A.P. Wound healing-A literature review. An. Bras. Dermatol. 2016, 91, 614-620. [CrossRef]

24. Zhu, G.; Wang, Q.; Lu, S.; Niu, Y. Hydrogen Peroxide: A potential wound therapeutic target. Med. Princ. Pract. 2017, 26, 301-308. [CrossRef]

25. Kurek-Górecka, A.; Komosinska-Vassev, K.; Rzepecka-Stojko, A.; Olczyk, P. Bee venom in wound healing. Molecules 2020, 26 , 148. [CrossRef]

26. Parfejevs, V.; Debbache, J.; Shakhova, O.; Schaefer, S.M.; Glausch, M.; Wegner, M.; Suter, U.; Riekstina, U.; Werner, S.; Sommer, L. Injury-activated glial cells promote wound healing of the adult skin in mice. Nat. Commun. 2018, 9, 236. [CrossRef] [PubMed]

27. An, Y.; Liu, W.J.; Xue, P.; Ma, Y.; Zhang, L.Q.; Zhu, B.; Qi, M.; Li, L.Y.; Zhang, Y.J.; Wang, Q.T.; et al. Autophagy promotes MSC-mediated vascularization in cutaneous wound healing via regulation of VEGF secretion. Cell Death Dis. $2018,9,58$. [CrossRef] [PubMed]

28. Asai, E.; Yamamoto, M.; Ueda, K.; Waguri, S. Spatiotemporal alterations of autophagy marker LC3 in rat skin fibroblasts during wound healing process. Fukushima J. Med. Sci. 2018, 64, 15-22. [CrossRef]

29. Wathoni, N.; Rusdiana, T.; Hasanah, A.N.; Muhtadi, A.; Pratiwi, E.D.; Mahmudah, R.; Mohammed, A.F.A.; Okajima, M.; Kaneko, T.; Arima, H. Sacran hydrogel film containing keratinocyte growth factor accelerates wound healing by stimulating fibroblast migration and re-epithelization. Chem. Pharm. Bull. 2019, 67, 849-854. [CrossRef]

30. Marconi, G.D.; Fonticoli, L.; Rajan, T.S.; Lanuti, P.; Della Rocca, Y.; Pierdomenico, S.D.; Trubiani, O.; Pizzicannella, J.; Diomede, F. Transforming growth factor-beta1 and human gingival fibroblast-to-myofibroblast differentiation: Molecular and morphological modifications. Front. Physiol. 2021, 12, 676512. [CrossRef]

31. Koike, Y.; Yozaki, M.; Utani, A.; Murota, H. Fibroblast growth factor 2 accelerates the epithelial-mesenchymal transition in keratinocytes during wound healing process. Sci. Rep. 2020, 10, 18545. [CrossRef]

32. Atiba, A.; Nishimura, M.; Kakinuma, S.; Hiraoka, T.; Goryo, M.; Shimada, Y.; Ueno, H.; Uzuka, Y. Aloe vera oral administration accelerates acute radiation-delayed wound healing by stimulating transforming growth factor- $\beta$ and fibroblast growth factor production. Am. J. Surg. 2011, 201, 809-818. [CrossRef] [PubMed]

33. Shabbir, A.; Cox, A.; Rodriguez-Menocal, L.; Salgado, M.; Van Badiavas, E. Mesenchymal stem cell exosomes induce proliferation and migration of normal and chronic wound fibroblasts, and enhance angiogenesis in vitro. Stem Cells Dev. 2015, 24, 1635-1647. [CrossRef] [PubMed]

34. Ning, J.; Zhao, H.; Chen, B.; Mi, E.Z.; Yang, Z.; Qing, W.; Lam, K.W.J.; Yi, B.; Chen, Q.; Gu, J.; et al. Argon mitigates impaired wound healing process and enhances wound healing in vitro and in vivo. Theranostics 2019, 9, 477-490. [CrossRef] [PubMed]

35. Casado-Díaz, A.; Quesada-Gómez, J.M.; Dorado, G. Extracellular vesicles derived from mesenchymal stem cells (MSC) in regenerative medicine: Applications in skin wound healing. Front. Bioeng. Biotechnol. 2020, 8, 146. [CrossRef]

36. Park, J.W.; Hwang, S.R.; Yoon, I.S. Advanced growth factor delivery systems in wound management and skin regeneration. Molecules 2017, 22, 1259. [CrossRef]

37. Hsu, C.; Chang, J. Clinical implications of growth factors in flexor tendon wound healing. J. Hand Surg. 2004, 29, 551-563. [CrossRef]

38. Wöltje, M.; Böbel, M.; Bienert, M.; Neuss, S.; Aibibu, D.; Cherif, C. Functionalized silk fibers from transgenic silkworms for wound healing applications: Surface presentation of bioactive epidermal growth factor. J. Biomed. Mater. Res. A 2018, 106, $2643-2652$. [CrossRef]

39. Pikuła, M.; Langa, P.; Kosikowska, P.; Trzonkowski, P. Stem cells and growth factors in wound healing. Postepy Hig. Med. Dosw. 2015, 69, 874-885. [CrossRef] [PubMed] 
40. Zarei, F.; Soleimaninejad, M. Role of growth factors and biomaterials in wound healing. Artif. Cells Nanomed. Biotechnol. 2018, 46, 906-911. [CrossRef]

41. Titan, A.L.; Foster, D.S.; Chang, J.; Longaker, M.T. Flexor tendon: Development, healing, adhesion formation, and contributing growth factors. Plast. Reconstr. Surg. 2019, 144, 639e-647e. [CrossRef] [PubMed]

42. Werner, S.; Grose, R. Regulation of wound healing by growth factors and cytokines. Physiol. Rev. 2003, 83, 835-870. [CrossRef]

43. Cowin, A.J.; Hatzirodos, N.; Holding, C.A.; Dunaiski, V.; Harries, R.H.; Rayner, T.E.; Fitridge, R.; Cooter, R.D.; Schultz, G.S.; Belford, D.A. Effect of healing on the expression of transforming growth factor beta(s) and their receptors in chronic venous leg ulcers. J. Investig. Dermatol. 2001, 117, 1282-1289. [CrossRef] [PubMed]

44. Ishihara, J.; Ishihara, A.; Starke, R.D.; Peghaire, C.R.; Smith, K.E.; McKinnon, T.A.J.; Tabata, Y.; Sasaki, K.; White, M.J.V.; Fukunaga K.; et al. The heparin binding domain of von Willebrand factor binds to growth factors and promotes angiogenesis in wound healing. Blood 2019, 13, 2559-2569. [CrossRef]

45. Berlanga-Acosta, J.; Fernández-Montequín, J.; Valdés-Pérez, C.; Savigne-Gutiérrez, W.; Mendoza-Marí, Y.; García-Ojalvo, A.; Falcón-Cama, V.; García Del Barco-Herrera, D.; Fernández-Mayola, M.; Pérez-Saad, H.; et al. Diabetic foot ulcers and epidermal growth factor: Revisiting the local delivery route for a successful outcome. Biomed. Res. Int. 2017, 2017, 2923759. [CrossRef]

46. Hui, Q.; Jin, Z.; Li, X.; Liu, C.; Wang, X. FGF Family: From drug development to clinical application. Int. J. Mol. Sci. 2018, 19, 1875. [CrossRef] [PubMed]

47. Song, Y.H.; Zhu, Y.T.; Ding, J.; Zhou, F.Y.; Xue, J.X.; Jung, J.H.; Li, Z.J.; Gao, W.Y. Distribution of fibroblast growth factors and their roles in skin fibroblast cell migration. Mol. Med. Rep. 2016, 14, 3336-3342. [CrossRef]

48. Maddaluno, L.; Urwyler, C.; Werner, S. Fibroblast growth factors: Key players in regeneration and tissue repair. Development 2017, 144, 4047-4060. [CrossRef]

49. El Agha, E.; Kosanovic, D.; Schermuly, R.T.; Bellusci, S. Role of fibroblast growth factors in organ regeneration and repair. Semin. Cell Dev. Biol. 2016, 53, 76-84. [CrossRef]

50. Rouabhia, M.; Park, H.; Meng, S.; Derbali, H.; Zhang, Z. Electrical stimulation promotes wound healing by enhancing dermal fibroblast activity and promoting myofibroblast transdifferentiation. PLoS ONE 2013, 8, e71660.

51. Yang, J.; Qiang, W.; Ren, S.; Yi, S.; Li, J.; Guan, L.; Du, L.; Guo, Y.; Hu, H.; Li, H.; et al. High-efficiency production of bioactive oleosin-basic fibroblast growth factor in A. thaliana and evaluation of wound healing. Gene 2018, 10, 69-76. [CrossRef]

52. Behr, B.; Panetta, N.J.; Longaker, M.T.; Quarto, N. Different endogenous threshold levels of Fibroblast Growth Factor-ligands determine the healing potential of frontal and parietal bones. Bone 2010, 47, 281-294. [CrossRef]

53. Carvalho, E.D.; Rosa, R.H.; Pereira, F.M.; Anbinder, A.L.; Mello, I.; Habitante, S.M.; Raldi, D.P. Effects of diode laser irradiation and fibroblast growth factor on periodontal healing of replanted teeth after extended extra-oral dry time. Dent. Traumatol. 2017, 33, 91-99. [CrossRef]

54. Akita, S.; Akino, K.; Tanaka, K.; Anraku, K.; Hirano, A. A basic fibroblast growth factor improves lower extremity wound healing with a porcine-derived skin substitute. J. Trauma Acute Care Surg. 2008, 64, 809-815. [CrossRef]

55. Zhang, J.B.; Li, H.; Zhang, L.; Wang, J.L. Observation of curative effect of recombinant human basic fibroblast growth factor combined with compound polymyxin B ointment and local application of insulin on wound healing of deep second-degree burn in diabetes mellitus: A randomized study. Eur. Rev. Med. Pharmacol. Sci. 2019, 23, 5987-5993.

56. Hom, D.B.; Unger, G.M.; Pernell, K.J.; Manivel, J.C. Improving surgical wound healing with basic fibroblast growth factor after radiation. Laryngoscope 2005, 115, 412-422. [CrossRef]

57. Peng, J.; Zhao, H.; Tu, C.; Xu, Z.; Ye, L.; Zhao, L.; Gu, Z.; Zhao, D.; Zhang, J.; Feng, Z. In situ hydrogel dressing loaded with heparin and basic fibroblast growth factor for accelerating wound healing in rat. Mater. Sci. Eng. C 2020, 116, 111169. [CrossRef]

58. Santa Maria, P.L.; Redmond, S.L.; Atlas, M.D.; Ghassemifar, R. Keratinocyte growth factor 1, fibroblast growth factor 2 and 10 in the healing tympanic membrane following perforation in rats. J. Mol. Histol. 2011, 42, 47-58. [CrossRef]

59. Ramos-Gonzalez, G.; Wittig, O.; Diaz-Solano, D.; Salazar, L.; Ayala-Grosso, C.; Cardier, J.E. Evaluation of epithelial progenitor cells and growth factors in a preclinical model of wound healing induced by mesenchymal stromal cells. Biosci. Rep. 2020, 40, BSR20200461. [CrossRef]

60. Xie, J.L.; Bian, H.N.; Qi, S.H.; Chen, H.D.; Li, H.D.; Xu, Y.B.; Li, T.Z.; Liu, X.S.; Liang, H.Z.; Xin, B.R.; et al. Basic fibroblast growth factor (bFGF) alleviates the scar of the rabbit ear model in wound healing. Wound Repair Regen. 2008, 16, 576-581. [CrossRef]

61. Akita, S.; Akino, K.; Imaizumi, T.; Hirano, A. Basic fibroblast growth factor accelerates and improves second-degree burn wound healing. Wound Repair Regen. 2008, 16, 635-641. [CrossRef]

62. Numata, Y.; Terui, T.; Okuyama, R.; Hirasawa, N.; Sugiura, Y.; Miyoshi, I.; Watanabe, T.; Kuramasu, A.; Tagami, H.; Ohtsu, H. The accelerating effect of histamine on the cutaneous wound-healing process through the action of basic fibroblast growth factor. J. Investig. Dermatol. 2006, 126, 1403-1409. [CrossRef] [PubMed]

63. Zhao, W.; Han, Q.; Lin, H.; Gao, Y.; Sun, W.; Zhao, Y.; Wang, B.; Chen, B.; Xiao, Z.; Dai, J. Improved neovascularization and wound repair by targeting human basic fibroblast growth factor (bFGF) to fibrin. J. Mol. Med. 2008, 86, 1127-1138. [CrossRef]

64. Guo, Y.; Xu, B.; Wang, Y.; Li, Y.; Si, H.; Zheng, X.; Chen, Z.; Chen, F.; Fan, D. Dramatic promotion of wound healing using a recombinant human-like collagen and bFGF cross-linked hydrogel by transglutaminase. J. Biomater. Sci. Polym. Ed. 2019, 30, 1591-1603. [CrossRef]

65. Hardwicke, J.; Schmaljohann, D.; Boyce, D.; Thomas, D. Epidermal growth factor therapy and wound healing-Past, present and future perspectives. Surgeon 2008, 6, 172-177. [CrossRef] 
66. Wu, M.; Ruan, J.; Zhong, B. Progress in human epidermal growth factor research. Sheng Wu Gong Cheng Xue Bao 2020, 36, 2813-2823.

67. Liu, Y.; Liu, Z.G. Role of epidermal growth factor and its receptor family in ocular surface wound healing. Zhonghua Yan Ke Za Zhi 2007, 43, 953-956. [PubMed]

68. Kim, H.; Kong, W.H.; Seong, K.Y.; Sung, D.K.; Jeong, H.; Kim, J.K.; Yang, S.Y.; Hahn, S.K. Hyaluronate-epidermal growth factor conjugate for skin wound healing and regeneration. Biomacromolecules 2016, 17, 3694-3705. [CrossRef]

69. Yumusak, N.; Yavuz, U.; Sarikaya, B.; Yucel, G. Effects of epidermal growth factor on reduction of the formation of thrombus and vessel wall healing in an experimental rat model. Bratisl. Lek. Listy 2017, 118, 752-758. [CrossRef] [PubMed]

70. Adam, A.B.; Özdamar, M.Y.; Esen, H.H.; Günel, E. Local effects of epidermal growth factor on the wound healing in esophageal anastomosis: An experimental study. Int. J. Pediatr. Otorhinolaryngol. 2017, 99, 8-12. [CrossRef]

71. Techapichetvanich, T.; Wanitphakdeedecha, R.; Iamphonrat, T.; Phothong, W.; Eimpunth, S.; Jane, H.I.; Manuskiatti, W. The effects of recombinant human epidermal growth factor containing ointment on wound healing and post inflammatory hyperpigmentation prevention after fractional ablative skin resurfacing: A split-face randomized controlled study. J. Cosmet. Dermatol. 2018, 17, 756-761. [CrossRef] [PubMed]

72. Berlanga-Acosta, J.; Camacho-Rodríguez, H.; Mendoza-Marí, Y.; Falcón-Cama, V.; García-Ojalvo, A.; Herrera-Martínez, L.; Guillén-Nieto, G. Epidermal growth factor in healing diabetic foot ulcers: From gene expression to tissue healing and systemic biomarker circulation. Medicc Rev. 2020, 22, 24-31.

73. Lu, K.J.; Wang, W.; Xu, X.L.; Jin, F.Y.; Qi, J.; Wang, X.J.; Kang, X.Q.; Zhu, M.L.; Huang, Q.L.; Yu, C.H.; et al. A dual deformable liposomal ointment functionalized with retinoic acid and epidermal growth factor for enhanced burn wound healing therapy. Biomater. Sci. 2019, 7, 2372-2382. [CrossRef]

74. Mohanty, C.; Pradhan, J. A human epidermal growth factor-curcumin bandage bioconjugate loaded with mesenchymal stem cell for in vivo diabetic wound healing. Mater. Sci. Eng. C 2020, 111, 110751. [CrossRef] [PubMed]

75. Sen, S.; Basak, P.; Prasad Sinha, B.; Maurye, P.; Kumar Jaiswal, K.; Das, P.; Kumar Mandal, T. Anti-inflammatory effect of epidermal growth factor conjugated silk fibroin immobilized polyurethane ameliorates diabetic burn wound healing. Int. J. Biol. Macromol. 2020, 143, 1009-1032. [CrossRef]

76. Kao, C.W.; Tseng, Y.Y.; Liu, K.S.; Liu, Y.W.; Chen, J.C.; He, H.L.; Kau, Y.C.; Liu, S.J. Anesthetics and human epidermal growth factor incorporated into anti-adhesive nanofibers provide sustained pain relief and promote healing of surgical wounds. Int. J. Nanomed. 2019, 29, 4007-4016. [CrossRef] [PubMed]

77. Kim, Y.S.; Sung, D.K.; Kong, W.H.; Kim, H.; Hahn, S.K. Synergistic effects of hyaluronate epidermal growth factor conjugate patch on chronic wound healing. Biomater. Sci. 2018, 6, 1020-1030. [CrossRef]

78. Palencia, L.; Das, A.; Palecek, S.P.; Thibeault, S.L.; Leydon, C. Epidermal growth factor mediated healing in stem cell-derived vocal fold mucosa. J. Surg. Res. 2015, 197, 32-38. [CrossRef]

79. Kaya, O.; Orhan, E.; Sapmaz-Metin, M.; Topçu-Tarladaçalışır, Y.; Gündüz, Ö.; Aydın, B. The effects of epidermal growth factor on early burn-wound progression in rats. Dermatol. Ther. 2020, 33, e13196. [CrossRef]

80. Lou, Z. The effect of epidermal growth factor on the pseudo-healing of traumatic tympanic membrane perforations. Braz. J. Otorhinolaryngol. 2021, 87, 53-58. [CrossRef]

81. Bui, T.Q.; Bui, Q.V.P.; Németh, D.; Hegyi, P.; Szakács, Z.; Rumbus, Z.; Tóth, B.; Emri, G.; Párniczky, A.; Sarlós, P.; et al. Epidermal Growth Factor is effective in the treatment of diabetic foot ulcers: Meta-analysis and systematic review. Int J. Environ. Res. Public Health 2019, 16, 2584. [CrossRef]

82. Dogan, S.; Demirer, S.; Kepenekci, I.; Erkek, B.; Kiziltay, A.; Hasirci, N.; Müftüoglu, S.; Nazikoglu, A.; Renda, N.; Dincer, U.D.; et al. Epidermal growth factor-containing wound closure enhances wound healing in non-diabetic and diabetic rats. Int. Wound J. 2009, 6, 107-115. [CrossRef]

83. Wei, S.; Wang, W.; Li, L.; Meng, H.Y.; Feng, C.Z.; Dong, Y.Y.; Fang, X.C.; Dong, Q.Q.; Jiang, W.; Xin, H.L.; et al. Recombinant human epidermal growth factor combined with vacuum sealing drainage for wound healing in Bama pigs. Mil. Med. Res. 2021, 8, 18.

84. Lin, W.C.; Yeh, I.T.; Hsiao, H.Y. Development and evaluation of multistructured and hierarchical epidermal growth factor-poly (epsilon -Caprolactone) scaffolds. IEEE Trans. Nanobioscience 2019, 18, 18-27. [CrossRef]

85. Kalay, Z.; Cevher, S.C. Oxidant and antioxidant events during epidermal growth factor therapy to cutaneous wound healing in rats. Int. Wound J. 2012, 9, 362-371. [CrossRef]

86. Poniatowski, Ł.A.; Wojdasiewicz, P.; Gasik, R.; Szukiewicz, D. Transforming growth factor beta family: Insight into the role of growth factors in regulation of fracture healing biology and potential clinical applications. Mediat. Inflamm. 2015, 2015, 137823. [CrossRef]

87. Khaghani, S.A.B.; Akbarova, G.; Soon, C.F.; Dilbazi, G. Effect of transforming growth factor-beta2 on biological regulation of multilayer primary chondrocyte culture. Cell Tissue Bank. 2018, 19, 763-775. [CrossRef]

88. Cheng, C.F.; Fan, J.; Fedesco, M.; Guan, S.; Li, Y.; Bandyopadhyay, B.; Bright, A.M.; Yerushalmi, D.; Liang, M.; Chen, M.; et al. Transforming growth factor alpha (TGFalpha)-stimulated secretion of HSP90alpha: Using the receptor LRP-1/CD91 to promote human skin cell migration against a TGFbeta-rich environment during wound healing. Mol. Cell Biol. 2008, 28, $3344-3358$. [CrossRef] [PubMed] 
89. Lagares, D. P311 in scar wars: Myofibroblasts lost without transforming growth factor beta translation. Am. J. Respir Cell Mol. Biol. 2019, 60, 139-140. [CrossRef] [PubMed]

90. Shu, D.Y.; Lovicu, F.J. Myofibroblast transdifferentiation: The dark force in ocular wound healing and fibrosis. Prog. Retin. Eye Res. 2017, 60, 44-65. [CrossRef]

91. Abe, Y.; Inagaki, K.; Fujiwara, A.; Kuriyama, K. Wound healing acceleration of a novel transforming growth factor-beta inducer, SEK-1005. Eur. J. Pharmacol. 2000, 17, 213-218. [CrossRef]

92. Klass, B.R.; Grobbelaar, A.O.; Rolfe, K.J. Transforming growth factor beta1 signalling, wound healing and repair: A multifunctional cytokine with clinical implications for wound repair, a delicate balance. Postgrad. Med. J. 2009, 85, 9-14. [CrossRef]

93. Farahani, R.M.; DiPietro, L.A. Microgravity and the implications for wound healing. Int. Wound J. 2008, 5, 552-561. [CrossRef]

94. Koch, R.M.; Roche, N.S.; Parks, W.T.; Ashcroft, G.S.; Letterio, J.J.; Roberts, A.B. Incisional wound healing in transforming growth factor-beta1 null mice. Wound Repair Regen. 2000, 8, 179-191. [CrossRef]

95. Peplow, P.V.; Baxter, G.D. Gene expression and release of growth factors during delayed wound healing: A review of studies in diabetic animals and possible combined laser phototherapy and growth factor treatment to enhance healing. Photomed. Laser Surg. 2012, 30, 617-36. [CrossRef] [PubMed]

96. Van den Boom, R.; Wilmink, J.M.; O'Kane, S.; Wood, J.; Ferguson, M.W. Transforming growth factor-beta levels during secondintention healing are related to the different course of wound contraction in horses and ponies. Wound Repair Regen. 2002, 10, 188-194. [CrossRef]

97. Rorison, P.; Thomlinson, A.; Hassan, Z.; Roberts, S.A.; Ferguson, M.W.; Shah, M. Longitudinal changes in plasma transforming growth factor beta-1 and post-burn scarring in children. Burns 2010, 36, 89-96. [CrossRef] [PubMed]

98. $\mathrm{Hu}, \mathrm{K}$; Olsen, B.R. The roles of vascular endothelial growth factor in bone repair and regeneration. Bone 2016, 91, 30-38. [CrossRef]

99. Hoeben, A.; Landuyt, B.; Highley, M.S.; Wildiers, H.; Van Oosterom, A.T.; De Bruijn, E.A. Vascular endothelial growth factor and angiogenesis. Pharmacol. Rev. 2004, 56, 549-580. [CrossRef]

100. Ong, H.T.; Dilley, R.J. Novel non-angiogenic role for mesenchymal stem cell-derived vascular endothelial growth factor on keratinocytes during wound healing. Cytokine Growth Factor Rev. 2018, 44, 69-79. [CrossRef]

101. Bao, P.; Kodra, A.; Tomic-Canic, M.; Golinko, M.S.; Ehrlich, H.P.; Brem, H. The role of vascular endothelial growth factor in wound healing. J. Surg. Res. 2009, 15, 347-358. [CrossRef]

102. Hajialyani, M.; Tewari, D.; Sobarzo-Sánchez, E.; Nabavi, S.M.; Farzaei, M.H.; Abdollahi, M. Natural product-based nanomedicines for wound healing purposes: Therapeutic targets and drug delivery systems. Int. J. Nanomed. 2018, 3, 5023-5043. [CrossRef]

103. Zubair, M.; Ahmad, J. Role of growth factors and cytokines in diabetic foot ulcer healing: A detailed review. Rev. Endocr. Metab. Disord. 2019, 20, 207-217. [CrossRef]

104. Seiwerth, S.; Rucman, R.; Turkovic, B.; Sever, M.; Klicek, R.; Radic, B.; Drmic, D.; Stupnisek, M.; Misic, M.; Vuletic, L.B.; et al. BPC 157 and standard angiogenic growth factors. gastrointestinal tract healing, lessons from tendon, ligament, muscle and bone healing. Curr. Pharm. Des. 2018, 24, 1972-1989. [CrossRef]

105. Lord, M.S.; Ellis, A.L.; Farrugia, B.L.; Whitelock, J.M.; Grenett, H.; Li, C.; O'Grady, R.L.; DeCarlo, A.A. Perlecan and vascular endothelial growth factor-encoding DNA-loaded chitosan scaffolds promote angiogenesis and wound healing. J. Control. Release 2017, 28, 48-61. [CrossRef]

106. Shi, Y.; Tu, L.X.; Deng, Q.; Zhang, Y.P.; Hu, Y.H.; Liu, D.W. Effects and mechanism of rat epidermal stem cells treated with exogenous vascular endothelial growth factor on healing of deep partial-thickness burn wounds in rats. Zhonghua Shao Shang Za Zhi 2020, 20, 195-203.

107. Li, X.; Liu, M.; Cheng, H.; Wang, Q.; Miao, C.; Ju, S.; Liu, F. Development of ionic liquid assisted-synthesized nano-silver combined with vascular endothelial growth factor as wound healing in the care of femoral fracture in the children after surgery. $J$. Photochem. Photobiol. B 2018, 183, 385-390. [CrossRef]

108. Vijayan, A.A.S.; Kumar, G.S.V. PEG grafted chitosan scaffold for dual growth factor delivery for enhanced wound healing. Sci. Rep. 2019, 16, 19165. [CrossRef]

109. Saaristo, A.; Tammela, T.; Farkkilā, A.; Kärkkäinen, M.; Suominen, E.; Yla-Herttuala, S.; Alitalo, K. Vascular endothelial growth factor-C accelerates diabetic wound healing. Am. J. Pathol. 2006, 169, 1080-1087. [CrossRef] [PubMed]

110. Bogachkov, Y.Y.; Chen, L.; Le Master, E.; Fancher, I.S.; Zhao, Y.; Aguilar, V.; Oh, M.J.; Wary, K.K.; DiPietro, L.A.; Levitan, I. LDL induces cholesterol loading and inhibits endothelial proliferation and angiogenesis in matrigels: Correlation with impaired angiogenesis during wound healing. Am. J. Physiol. Cell Physiol. 2020, 1, C762-C776. [CrossRef] [PubMed]

111. Stuard, W.L.; Titone, R.; Robertson, D.M. The IGF/Insulin-IGFBP axis in corneal development, wound healing, and disease. Front. Endocrinol. 2020, 11, 24. [CrossRef]

112. Botusan, I.R.; Zheng, X.; Narayanan, S.; Grünler, J.; Sunkari, V.G.; Calissendorff, F.S.; Ansurudeen, I.; Illies, C.; Svensson, J.; Jansson, J.O.; et al. Deficiency of liver-derived insulin-like growth factor-I (IGF-I) does not interfere with the skin wound healing rate. PLOS ONE 2018, 13, e0193084. [CrossRef]

113. Schmidt, M.B.; Chen, E.H.; Lynch, S.E. A review of the effects of insulin-like growth factor and platelet derived growth factor on in vivo cartilage healing and repair. Osteoarthr. Cartil. 2006, 14, 403-412. [CrossRef]

114. Gong, F.; Zhao, F.; Cheng, S.L.; Ding, D.; Zhang, B.W.; Li, X.L.; Huang, Y.L. Effect of insulin-like growth factor-1 on promoting healing of skin ulcers in diabetic rats. J. Biol. Regul. Homeost. Agents 2019, 33, 687-694. [PubMed] 
115. Shinchi, M.; Kushibiki, T.; Mayumi, Y.; Ito, K.; Asano, T.; Ishihara, M.; Horiguchi, A. Insulin-like growth factor 1 sustained-release collagen on urethral catheter prevents stricture after urethral injury in a rabbit model. Int. J. Urol. 2019, 26, 572-577. [CrossRef] [PubMed]

116. Cieszkowski, J.; Warzecha, Z.; Ceranowicz, P.; Ceranowicz, D.; Kusnierz-Cabala, B.; Pedziwiatr, M.; Dembinski, M.; Ambrozy, T.; Kaczmarzyk, T.; Pihut, M.; et al. Therapeutic effect of exogenous ghrelin in the healing of gingival ulcers is mediated by the release of endogenous growth hormone and insulin-like growth factor-1. J. Physiol. Pharmacol. 2017, 68, 609-617.

117. Todorović, V.; Pesko, P.; Micev, M.; Bjelović, M.; Budec, M.; Mićić, M.; Brasanac, D.; Ilić-Stojanović, O. Insulin-like growth factor-I in wound healing of rat skin. Regul. Pept. 2008, 9, 7-13. [CrossRef]

118. Reckenbeil, J.; Kraus, D.; Stark, H.; Rath-Deschner, B.; Jäger, A.; Wenghoefer, M.; Winter, J.; Götz, W. Insulin-like growth factor 1 (IGF1) affects proliferation and differentiation and wound healing processes in an inflammatory environment with p38 controlling early osteoblast differentiation in periodontal ligament cells. Arch. Oral Biol. 2017, 73, 142-150. [CrossRef]

119. Balaji, S.; LeSaint, M.; Bhattacharya, S.S.; Moles, C.; Dhamija, Y.; Kidd, M.; Le, L.D.; King, A.; Shaaban, A.; Crombleholme, T.M.; et al. Adenoviral-mediated gene transfer of insulin-like growth factor 1 enhances wound healing and induces angiogenesis. $J$. Surg. Res. 2014, 190, 367-377. [CrossRef]

120. Achar, R.A.; Silva, T.C.; Achar, E.; Martines, R.B.; Machado, J.L. Use of insulin-like growth factor in the healing of open wounds in diabetic and non-diabetic rats. Acta Cir. Bras. 2014, 29, 125-131. [CrossRef]

121. Pastar, I.; Stojadinovic, O.; Yin, N.C.; Ramirez, H.; Nusbaum, A.G.; Sawaya, A.; Patel, S.B.; Khalid, L.; Isseroff, R.R.; Tomic-Canic, M. Epithelialization in wound healing: A comprehensive review. Adv. Wound Care 2014, 3, 445-464. [CrossRef] [PubMed]

122. Pan, A.; Zhong, M.; Wu, H.; Peng, Y.; Xia, H.; Tang, Q.; Huang, Q.; Wei, L.; Xiao, L.; Peng, C. Topical application of keratinocyte growth factor conjugated gold nanoparticles accelerate wound healing. Nanomedicine 2018, 14, 1619-1628. [CrossRef] [PubMed]

123. Denzinger, M.; Link, A.; Kurz, J.; Krauss, S.; Thoma, R.; Schlensak, C.; Wendel, H.P.; Krajewski, S. Keratinocyte growth factor modified messenger RNA accelerating cell proliferation and migration of keratinocytes. Nucleic Acid Ther. 2018, 28, 335-347. [CrossRef] [PubMed]

124. Devalliere, J.; Dooley, K.; Hu, Y.; Kelangi, S.S.; Uygun, B.E.; Yarmush, M.L. Co-delivery of a growth factor and a tissue-protective molecule using elastin biopolymers accelerates wound healing in diabetic mice. Biomaterials 2017, 141, 149-160. [CrossRef]

125. Bienert, M.; Hoss, M.; Bartneck, M.; Weinandy, S.; Böbel, M.; Jockenhövel, S.; Knüchel, R.; Pottbacker, K.; Wöltje, M.; JahnenDechent, W.; et al. Growth factor-functionalized silk membranes support wound healing in vitro. Biomed. Mater. 2017, 16, 045023. [CrossRef]

126. Chomiski, V.; Gragnani, A.; Bonucci, J.; Correa, S.A.; Noronha, S.M.; Ferreira, L.M. Keratinocyte growth factor and the expression of wound-healing-related genes in primary human keratinocytes from burn patients. Acta Cir. Bras. 2016, 31, 505-512. [CrossRef]

127. Cai, J.; Zhou, Q.; Wang, Z.; Guo, R.; Yang, R.; Yang, X.; Li, W.; Ahmad, N.; Chen, Q.; Hui, Q.; et al. Comparative analysis of KGF-2 and bFGF in prevention of excessive wound healing and scar formation in a corneal alkali burn model. Cornea 2019, 38, 1430-1437. [CrossRef]

128. Sen-Britain, S.; Britain, D.M.; Hicks, W.L., Jr.; Gardella, J.A., Jr. ToF-SIMS and TIRF microscopy investigation on the effects of HEMA copolymer surface chemistry on spatial localization, surface intensity, and release of fluorescently labeled keratinocyte growth factor. Biointerphases 2019, 23, 051003. [CrossRef]

129. Dougan, M.; Dranoff, G.; Dougan, S.K. GM-CSF, IL-3, and IL-5 family of cytokines: Regulators of inflammation. Immunity 2019, 16, 796-811. [CrossRef]

130. Brem, H.; Howell, R.; Criscitelli, T.; Senderowicz, A.; Siegart, N.; Gorenstein, S.; Gillette, B. Practical application of granulocytemacrophage colony-stimulating factor (GM-CSF) in patients with wounds. Surg. Technol. Int. 2018, 1, 61-66.

131. Fang, Y.; Gong, S.J.; Xu, Y.H.; Hambly, B.D.; Bao, S. Impairedcutaneous wound healing in granulocyte/macrophage colonystimulating factor knockout mice. Br. J. Dermatol. 2007, 157, 458-65. [CrossRef]

132. Rho, C.R.; Park, M.Y.; Kang, S. Effects of granulocyte-macrophage colony-stimulating (GM-CSF) factor on corneal epithelial cells in corneal wound healing model. PLoS ONE 2015, 16, e0138020. [CrossRef] [PubMed]

133. Yan, D.; Liu, S.; Zhao, X.; Bian, H.; Yao, X.; Xing, J.; Sun, W.; Chen, X. Recombinant human granulocyte macrophage colony stimulating factor in deep second-degree burn wound healing. Medicine 2017, 96, e6881. [CrossRef]

134. Li, J.; Liu, W.; Zhang, G.; Wang, D.; Lou, H.; Duang, J. Effectiveness of recombinanthuman granulocyte macrophage colonystimulating factor for treating deep second-degree burns: A systematic review and meta-analysis. BMJ Mil. Health 2020, 166, 352-357. [CrossRef] [PubMed]

135. Chi, Y.F.; Chai, J.K.; Luo, H.M.; Zhang, Q.X.; Feng, R. Safety of recombinant human granulocyte-macrophage colony-stimulating factor in healing pediatric severe burns. Genet. Mol. Res. 2015, 31, 2735-2741. [CrossRef] [PubMed]

136. Sun, Z.A.; Zhang, X.H.; Xue, Y.; Zhou, X.; Chen, X.X.; Gao, X.X.; Yu, J.A. Effects of recombinanthuman granulocyte macrophage colony stimulating factor gel on treatment of full-thickness frostbite wounds on foot and hand. Zhonghua Shao Shang Za Zhi $\mathbf{2 0 2 0}$ 20,117-121.

137. Lim, J.Y.; Choi, B.H.; Lee, S.; Jang, Y.H.; Choi, J.S.; Kim, Y.M. Regulation of wound healing by granulocyte-macrophage colony-stimulating factor after vocal fold injury. PLOS ONE 2013, 8, e54256.

138. Fang, Y.; Shen, J.; Yao, M.; Beagley, K.W.; Hambly, B.D.; Bao, S. Granulocyte-macrophage colony stimulating factor enhances wound healing in diabetes via upregulation of proinflammatory cytokines. Br. J. Dermatol. 2010, 162, 478-486. [CrossRef] 
139. Haisa, M.; Okochi, H.; Grotendorst, G.R. Elevated levels of PDGF alpha receptors in keloid fibroblasts contribute to an enhanced response to PDGF. J. Investig. Dermatol. 1994, 103, 560-563. [CrossRef]

140. Barrientos, S.; Brem, H.; Stojadinovic, O.; Tomic-Canic, M. Clinical application of growth factors and cytokines in wound healing. Wound Repair Regen. 2014, 22, 569-578. [CrossRef]

141. Demaria, M.; Ohtani, N.; Youssef, S.A.; Rodier, F.; Toussaint, W.; Mitchell, J.R.; Laberge, R.M.; Vijg, J.; Van Steeg, H.; Dollé, M.E.; et al. An essential role for senescent cells in optimal wound healing through secretion of PDGF-AA. Dev. Cell 2014, 22, 722-733. [CrossRef] [PubMed]

142. Zehra, M.; Zubairi, W.; Hasan, A.; Butt, H.; Ramzan, A.; Azam, M.; Mehmood, A.; Falahati, M.; Chaudhry, A.A.; Rehman, I.U.; et al. Oxygen generating polymeric nano fibers that stimulate angiogenesis and show efficient wound healing in a diabetic wound model. Int. J. Nanomed. 2020, 18, 3511-3522. [CrossRef]

143. Tanaka, T.; Minami, A.; Uchida, J.; Nakatani, T. Potential of hyperbaric oxygen in urological diseases. Int. J. Urol. 2019, 26, 860-867. [CrossRef]

144. Chandan, K.S. Wound healing essentials: Let there be oxygen. Wound Repair Regen. 2009, 17, 1-18.

145. Lin, W.; Qi, X.; Guo, W.; Liang, D.; Chen, H.; Lin, B.; Deng, X. A barrier against reactive oxygen species: Chitosan/acellular dermal matrix scaffold enhances stem cell retention and improves cutaneous wound healing. Stem Cell Res. Ther. 2020, 7, 383. [CrossRef]

146. Fosen, K.M.; Thom, S.R. Hyperbaric oxygen, vasculogenic stem cells, and wound healing. Antioxid. Redox Signal. 2014, 21, 1634-1647. [CrossRef] [PubMed]

147. Nouvong, A.; Ambrus, A.M.; Zhang, E.R.; Hultman, L.; Coller, H.A. Reactive oxygen species and bacterial biofilms in diabetic wound healing. Physiol. Genom. 2016, 48, 889-896. [CrossRef]

148. Deng, Z.; Shi, F.; Zhou, Z.; Sun, F.; Sun, M.H.; Sun, Q.; Chen, L.; Li, D.; Jiang, C.Y.; Zhao, R.Z.; et al. M1 macrophage mediated increased reactive oxygen species (ROS) influence wound healing via the MAPK signaling in vitro and in vivo. Toxicol. Appl. Pharmacol. 2019, 366, 83-95. [CrossRef]

149. Xiao, K.; Liu, C.; Tu, Z.; Xu, Q.; Chen, S.; Zhang, Y.; Wang, X.; Zhang, J.; Hu, C.A.; Liu, Y. Activation of the NF-kappaB and MAPK Signaling pathways contributes to the inflammatory responses, but not cell injury, in IPEC-1 cells challenged with hydrogen peroxide. Oxid. Med. Cell Longev. 2020, 2020, 5803639. [CrossRef] [PubMed]

150. LeBert, D.; Squirrell, J.M.; Freisinger, C.; Rindy, J.; Golenberg, N.; Frecentese, G.; Gibson, A.; Eliceiri, K.W.; Huttenlocher, A. Damage-induced reactive oxygen species regulate vimentin and dynamic collagen-based projections to mediate wound repair. Elife 2018, 7, e30703. [CrossRef] [PubMed]

151. André-Lévigne, D.; Modarressi, A.; Pepper, M.S.; Pittet-Cuénod, B. Reactive oxygen species and NOX enzymes are emerging as key players in cutaneous wound repair. Int. J. Mol. Sci. 2017, 18, 2149. [CrossRef] [PubMed]

152. Butin-Israeli, V.; Bui, T.M.; Wiesolek, H.L.; Mascarenhas, L.; Lee, J.J.; Mehl, L.C.; Knutson, K.R.; Adam, S.A.; Goldman, R.D.; Beyder, A.; et al. Neutrophil-induced genomic instability impedes resolution of inflammation and wound healing. J. Clin. Investig. 2019, 129, 712-726. [CrossRef]

153. Sardella, E.; Mola, M.G.; Gristina, R.; Piccione, M.; Veronico, V.; Bellis, M.; Cibelli, A.; Buttiglione, M.; Armenise, V.; Favia, P.; et al. A synergistic effect of reactive oxygen and reactive nitrogen species in plasma activated liquid media triggers astrocyte wound healing. Int. J. Mol. Sci. 2020, 21, 3343. [CrossRef] [PubMed]

154. Thi, P.L.; Lee, Y.; Tran, D.L.; Thi, T.T.H.; Kang, J.I.; Park, K.M.; Park, K.D. In situ forming and reactive oxygen species-scavenging gelatin hydrogels for enhancing wound healing efficacy. Acta Biomater. 2020, 103, 103,142-152. [CrossRef]

155. Loo, A.E.; Ho, R.; Halliwell, B. Mechanism of hydrogen peroxide-induced keratinocyte migration in a scratch-wound model. Free Radic. Biol. Med. 2011, 15, 884-892. [CrossRef]

156. Fan, Z.; Wang, X.; Zhang, M.; Zhao, C.; Mei, C.; Li, P. MAPK pathway inhibitors attenuated hydrogen peroxide induced damage in neural cells. Biomed. Res. Int. 2019, 2019, 5962014. [CrossRef]

157. Hou, B.; Cai, W.; Chen, T.; Zhang, Z.; Gong, H.; Yang, W.; Qiu, L. Vaccarin hastens wound healing by promoting angiogenesis via activation of MAPK/ERK and PI3K/AKT signaling pathways in vivo. Acta Cir. Bras. 2020, 7, 201901202. [CrossRef]

158. Wahedi, H.M.; Chae, J.K.; Subedi, L.; Kang, M.C.; Cho, H.; Kim, S.; Kim, S.Y. NED416, a novel synthetic Sirt1 activator, promotes cutaneous wound healing via the MAPK/Rho pathway. Int. J. Mol. Med. 2020, 46, 149-158. [CrossRef]

159. Lee, B.C.; Song, J.; Lee, A.; Cho, D.; Kim, T.S. Visfatin promotes wound healing through the activation of ERK1/2 and JNK1/2 Pathway. Int. J. Mol. Sci. 2018, 19, 3642. [CrossRef] [PubMed]

160. Escuin-Ordinas, H.; Li, S.; Xie, M.W.; Sun, L.; Hugo, W.; Huang, R.R.; Jiao, J.; de-Faria, F.M.; Realegeno, S.; Krystofinski, P.; et al. Cutaneous wound healing through paradoxical MAPK activation by BRAF inhibitors. Nat. Commun. 2016, 7, 2348. [CrossRef]

161. Chen, J.; Chen, Y.; Chen, Y.; Yang, Z.; You, B.; Ruan, Y.C.; Peng, Y. Epidermal CFTR suppresses MAPK/NF-kappaB to promote cutaneous wound healing. Cell Physiol. Biochem. 2016, 39, 2262-2274. [CrossRef]

162. Yuan, X.; Han, L.; Fu, P.; Zeng, H.; Lv, C.; Chang, W.; Runyon, R.S.; Ishii, M.; Han, L.; Liu, K.; et al. Cinnamaldehyde accelerates wound healing by promoting angiogenesis via up-regulation of PI3K and MAPK signalling pathways. Lab. Investig. 2018, 98, 783-798. [CrossRef]

163. Su, L.; Fu, L.; Li, X.; Zhang, Y.; Li, Z.; Wu, X.; Li, Y.; Bai, X.; Hu, D. Loss of CAR promotes migration and proliferation of HaCaT cells, and accelerates wound healing in rats via Src-p38 MAPK pathway. Sci. Rep. 2016, 6, 19735. [CrossRef] 
164. Liu, C.; Huang, J.; Li, H.; Yang, Z.; Zeng, Y.; Liu, J.; Hao, Y.; Li, R. Ghrelin accelerates wound healing through GHS-R1a-mediated MAPK-NF-kappaB/GR signaling pathways in combined radiation and burn injury in rats. Sci. Rep. 2016, 7, 27499. [CrossRef]

165. Zhang, L.; Xu, P.; Wang, X.; Zhang, M.; Yan, Y.; Chen, Y.; Zhang, L.; Zhang, L. Activin B regulates adipose-derived mesenchymal stem cells to promote skin wound healing via activation of the MAPK signalling pathway. Int. J. Biochem. Cell Biol. 2017, 87, 69-76. [CrossRef]

166. Cui, D.; Xiao, J.; Zhou, Y.; Zhou, X.; Liu, Y.; Peng, Y.; Yu, Y.; Li, H.; Zhou, X.; Yuan, Q.; et al. Epiregulin enhances odontoblastic differentiation of dental pulp stem cells via activating MAPK signalling pathway. Cell Prolif. 2019, 52, e12680. [CrossRef]

167. Pereira, B.F.; Xue, M.; Maia, G.L.A.; Leite, R.A.; Helena, P.C.; Jackson, C.J. Lupeol, a pentacyclic triterpene, promotes migration, wound closure, and contractile effect in vitro: Possible involvement of PI3K/Akt and p38/ERK/MAPK pathways. Molecules 2018, 30, 2819. [CrossRef] [PubMed]

168. Schultze, S.M.; Hemmings, B.A.; Niessen, M.; Tschopp, O. PI3K/AKT, MAPK and AMPK signalling: Protein kinases in glucose homeostasis. Expert. Rev. Mol. Med. 2012, 14, E1. [CrossRef] [PubMed]

169. Moldogazieva, N.T.; Lutsenko, S.V.; Terentiev, A.A. Reactive oxygen and nitrogen species-induced protein modifications: Implication in carcinogenesis and anticancer therapy. Cancer Res. 2018, 78, 6040-6047. [CrossRef] [PubMed]

170. Sánchez-de-Diego, C.; Valer, J.A.; Pimenta-Lopes, C.; Rosa, J.L.; Ventura, F. Interplay between BMPs and reactive oxygen species in cell signaling and pathology. Biomolecules 2019, 9, 534. [CrossRef]

171. Ornitz, D.M.; Itoh, N. The fibroblast growth factor signaling pathway. Wiley Interdiscip. Rev. Dev. Biol. 2015, 4, 215-266. [CrossRef] [PubMed]

172. Scarpello, J.H.; Howlett, H.C. Metformin therapy and clinical uses. Diabetes Vasc. Dis. Res. 2008, 5, 157-167. [CrossRef] [PubMed]

173. Inzucchi, S.E.; Bergenstal, R.M.; Buse, J.B.; Diamant, M.; Ferrannini, E.; Nauck, M.; Peters, A.L.; Tsapas, A.; Wender, R.; Matthews, D.R. American Diabetes Association (ADA); european association for the study of diabetes (EASD). Management of hyperglycemia in type 2 diabetes: A patient-centered approach: Position statement of the American diabetes association (ADA) and the European association for the study of diabetes (EASD). Diabetes Care 2012, 35, 1364-1379.

174. Jeschke, M.G.; Abdullahi, A.; Burnett, M.; Rehou, S.; Stanojcic, M. Glucose control in severely burned patients using metformin: An interim safety and efficacy analysis of a phase II randomized controlled trial. Ann. Surg. 2016, 264, 518-527. [CrossRef] [PubMed]

175. Rena, G.; Hardie, D.G.; Pearson, E.R. The mechanisms of action of metformin. Diabetologia 2017, 60, 1577-1585. [CrossRef]

176. Gore, D.C.; Wolf, S.E.; Sanford, A.; Herndon, D.N.; Wolfe, R.R. Influence of metformin on glucose intolerance and muscle catabolism following severe burn injury. Ann. Surg. 2005, 241, 334-342. [CrossRef] [PubMed]

177. Bridges, H.R.; Jones, A.J.; Pollak, M.N.; Hirst, J. Effects of metformin and other biguanides on oxidative phosphorylation in mitochondria. Biochem. J. 2014, 462, 475-487. [CrossRef] [PubMed]

178. Saisho, Y. Metformin and inflammation: Its potential beyond glucose-lowering effect. Endocr. Metab. Immune Disord. -Drug Targets 2015, 15, 196-205. [CrossRef]

179. Xu, T.; Wu, X.; Lu, X.; Liang, Y.; Mao, Y.; Loor, J.J.; Yang, Z. Metformin activated AMPK signaling contributes to the alleviation of LPS-induced inflammatory responses in bovine mammary epithelial cells. BMC Vet. Res. 2021, 17, 97. [CrossRef] [PubMed]

180. Arbab, A.A.I.; Lu, X.; Abdalla, I.M.; Idris, A.A.; Chen, Z.; Li, M.; Mao, Y.; Xu, T.; Yang, Z. Metformin inhibits lipoteichoic acid-induced oxidative stress and inflammation through AMPK/NRF2/NF- $\mathrm{kB}$ signaling pathway in bovine mammary epithelial cells. Front. Vet. Sci. 2021, 8, 661380. [CrossRef]

181. Song, Y.M.; Lee, W.K.; Lee, Y.H.; Kang, E.S.; Cha, B.S.; Lee, B.W. Metformin restores parkin-mediated mitophagy, suppressed by cytosolic p53. Int. J. Mol. Sci. 2016, 17, 122. [CrossRef] [PubMed]

182. Doblado, L.; Lueck, C.; Rey, C.; Samhan-Arias, A.K.; Prieto, I.; Stacchiotti, A.; Monsalve, M. Mitophagy in human diseases. Int. J. Mol. Sci. 2021, 22, 3903. [CrossRef]

183. Diaz, E.C.; Herndon, D.N.; Porter, C.; Sidossis, L.S.; Suman, O.E.; Børsheim, E. Effects of pharmacological interventions on muscle protein synthesis and breakdown in recovery from burns. Burns 2015, 41, 649-657. [CrossRef] [PubMed]

184. Yu, H.M.; Kim, S.J.; Chun, S.W.; Park, K.Y.; Lim, D.M.; Lee, J.M.; Hong, J.H.; Park, K.S. A comparison study on efficacy, insulin sensitivity and safety of glimepiride/metformin fixed dose combination versus glimepiride single therapy on type 2 diabetes mellitus patients with basal insulin therapy. Diabetes Res. Clin. Pract. 2019, 155, 107796. [CrossRef]

185. Cree-Green, M.; Bergman, B.C.; Cengiz, E.; Fox, L.A.; Hannon, T.S.; Miller, K.; Nathan, B.; Pyle, L.; Kahn, D.; Tansey, M. Metformin improves peripheral insulin sensitivity in youth with type 1 diabetes. J. Clin. Endocrinol. Metab. 2019, 104, 3265-3278. [CrossRef] [PubMed]

186. Sikorskaya, K.; Zarzecka, I.; Ejikeme, U.; Russell, J. The use of metformin as an add-on therapy to insulin in the treatment of poorly controlled type 1 diabetes mellitus in adolescents. Metab. Open 2021, 9, 100080. [CrossRef]

187. Jeschke, M.G. Clinical review: Glucose control in severely burned patients—current best practice. Crit. Care 2013, 17, 232. [CrossRef]

188. Shawky, L.M.; El Bana, E.A.; Morsi, A.A. Stem cells and metformin synergistically promote healing in experimentally induced cutaneous wound injury in diabetic rats. Folia Histochem. Cytobiol. 2019, 57, 127-138. [CrossRef]

189. Taleb, S.; Moghaddas, P.; Rahimi Balaei, M.; Taleb, S.; Rahimpour, S.; Abbasi, A.; Ejtemaei-Mehr, S.; Dehpour, A.R. Metformin improves skin flap survival through nitric oxide system. J. Surg. Res. 2014, 192, 686-691. [CrossRef] 
190. Wu, H.; Ding, J.; Li, S.; Lin, J.; Jiang, R.; Lin, C.; Dai, L.; Xie, C.; Lin, D.; Xu, H.; et al. Metformin Promotes the Survival of Random-Pattern Skin Flaps by Inducing Autophagy via the AMPK-mTOR-TFEB signaling pathway. Int. J. Biol. Sci. 2019, 15, 325-340. [CrossRef]

191. Young, N.; Kamireddy, A.; Van Nostrand, J.; Eichner, L.; Shokhirev, M.; Dayn, Y.; Shaw, R.J. AMPK governs lineage specification through Tfeb-dependent regulation of lysosomes. Genes Dev. 2016, 30, 535-552. [CrossRef] [PubMed]

192. Ochoa-Gonzalez, F.; Cervantes-Villagrana, A.R.; Fernandez-Ruiz, J.C.; Nava-Ramirez, H.S.; Hernandez-Correa, A.C.; EncisoMoreno, J.A.; Castañeda-Delgado, J.E. Metformin induces cell cycle arrest, reduced proliferation, wound healing impairment in vivo and is associated to clinical outcomes in diabetic foot ulcer patients. PLOS ONE 2016, 11, e0150900.

193. Nair, V.; Sreevalsan, S.; Basha, R.; Abdelrahim, M.; Abudayyeh, A.; Rodrigues, H.A.; Safe, S. Mechanism of metformin-dependent inhibition of mammalian target of rapamycin (mTOR) and Ras activity in pancreatic cancer: Role of specificity protein (Sp) transcription factors. J. Biol. Chem. 2014, 3, 27692-27701. [CrossRef] [PubMed]

194. Pérez-Revuelta, B.I.; Hettich, M.M.; Ciociaro, A.; Rotermund, C.; Kahle, P.J.; Krauss, S.; Di Monte, D.A. Metformin lowers Serphosphorylated $\alpha$-synuclein levels via mTOR- dependent protein phosphatase 2A activation. Cell Death Dis. 2014, 8, 1209. [CrossRef] [PubMed]

195. Wetzel, M.; Herndon, D.; Finnerty, C. Metformin down-regulates epithelial-mesenchymal transition (EMT) in fibroblasts from burned patients. Cancer Metab. 2014, 2, P84. [CrossRef] 